Journal of

Entreprenuership and

Project Management

(JEPM)

COST RISK'S RELIABILITY AND VALIDITY OF RESIDENTIAL BUILDING PROJECT'S WHOLE LIFE CYCLE IN THE UNITED ARAB EMIRATES

Journal of Entrepreneurship and Project Management, Vol. 6 No. 1 (2021), 90-114.

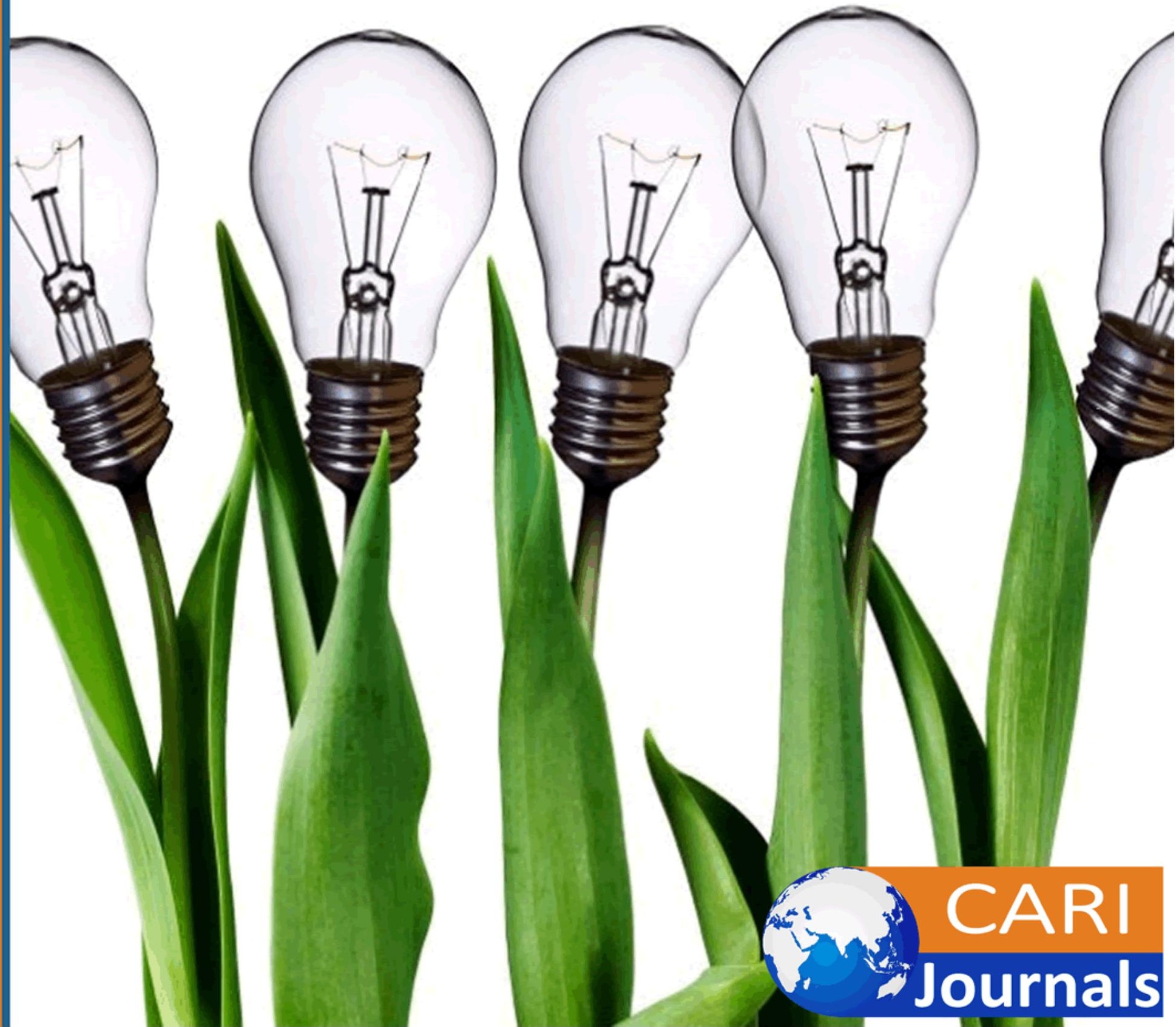




\title{
COST RISK'S RELIABILITY AND VALIDITY OF RESIDENTIAL BUILDING PROJECT'S WHOLE LIFE CYCLE IN THE UNITED ARAB EMIRATES
}

\author{
Ahmed Sadek \\ The British University in Dubai \\ 2015132021@student.buid.ac.ae
}

\begin{abstract}
Purpose - Project management cost and risk modelling is experiencing the challenge of identifying cost risks values to maintain accurate modelling, estimating, and assessment. Latest research focused on cost and risk modelling and estimation. The significance of cost risks numerical values come from its ability to be used in many different analysis and approaches. This article aims to identify residential building projects' whole life cycle cost risks numerical values in UAE at the preconstruction stage and ensure its reliability and validity.

Methodology - The approach of this research is pure quantitative. The methodology of this research is to collect data though conducting face-to-face interviews quantitatively (i.e., cost risks values). The survey is using PMBOK risk matrix (i.e., probability vs. impact). Finally, data correlation and regression modelling ware done to ensure the reliability and validity of each cost risk value.

Findings - This paper was able to deliver reliable and valid residential project's whole life cycle cost risks values (i.e., 117 cost risks) for direct use in future research or practical professional cost analysis.

Unique contribution to theory, practice and policy - This article contribution to the project management body of knowledge is to collect all relevant cost risks (i.e., 117 cost risks) and obtain their values from UAE field experts for the first time. The provided values are for residential project in UAE only. The perspective of how to look to cost risks values in this article (i.e., contractors' and clients' views) should be considered at the time of using the data. The consultancy services organizations will have different cost risks because they do not deal with delivering the final product, but they provide supporting services (i.e., design and supervision) to facilitate delivering the project.
\end{abstract}

Keywords: Cost Risks, Correlation, Regression, Experts, Building, Reliability, Validity, Project's WLC.

\section{INTRODUCTION}

This article introduces the first numerical values of residential project's whole life cycle cost risks in the United Arab Emirates. The implementation of data collection and validation procedures will be detailed following the explained and justified research methodology design of this research. The literature review, problem statement, and research methodology will be presented and detailed in the beginning. Then, in this article, there are four main arguments related to data collection and analysis, including (1) data collection strategy, (2) experts' competencies, (3) data correlation analysis, and (4) data regression analysis. Finally, the originality of this research is presented along with its theoretical implication, practice implication, and limitations for future research. 


\section{LITERATURE REVIEW}

Financial management in the construction industry has many paths and ways, elements and factors, and concerns and issues regarding the process designing and engineering (Yana et al., 2015; Rodrigues \& Bowers, 1996; Khang \& Myint, 1999). For example, high pressure of clients on contractors, subcontractors, and even the consultant to achieve the required quality and time increases costs rise significantly (Yana et al., 2015; Rodrigues \& Bowers, 1996; Khang \& Myint, 1999). The design stage needs to identify complexity in each of its parts to achieve a successful execution and deliver the designed product with the lowest tolerance and using rare and/or expensive equipment, materials, and other resources optimally (Yana et al., 2015; Rodrigues \& Bowers, 1996; Khang \& Myint, 1999). On the other hand, some researchers such as James (2014) found that managing team members and their competencies contain most financial management factors in the construction industry, including managing human resources as a primary core subject (James, 2014). For instance, the subject assigned to employees' wedges should be carefully designed (James, 2014). Also, experience, capabilities, and competencies have to match each employee's offered packages (James, 2014). Therefore, it is crucial to consider updated critical success factors and risks to improve the final modelling outputs in this research study. The values of these risks can be obtained by field experts (Mieg, 2009; Zimmermann \& Eber, 2017; Flores-Colen et al., 2010). However, those experts are not sustainable in the same company due to the challenges of having a large number of expatriate workers in the United Arab Emirates (Naithani \& Jha, 2009; AlMazrouei \& Pech, 2015; Saheem, 2016). The work force in UAE, specially in the construction and project base industries, are contributing to organizations for a certain period (i.e. 1 year or more) (Naithani \& Jha, 2009; AlMazrouei \& Pech, 2015; Saheem, 2016). Those professionals are representing a wide cultural diversity (Naithani \& Jha, 2009; AlMazrouei \& Pech, 2015; Saheem, 2016). The experience they have is shaped based on projects, events, and jobs inside and outside the United Arab Emirates (Naithani \& Jha, 2009; AlMazrouei \& Pech, 2015; Saheem, 2016).

Besides, the economic structure of the United Arab Emirates has been changed. It is changing to reduce construction cost for all executers in the private sector as a government financial initiative to minimize risk and enhance economic performance (Radhi 2009). Furthermore, construction financial management had to include risk assessment plans regarding value engineering of resulted products compared to the consumed amount of money and resources (Ibn-Homaid \& Tijani, 2015). This is a significant issue, especially when the contractor fails the project execution stage and hand over the work to another contractor or holds it for some time; hence, it can affect banks' capability to finance construction projects and bankrupt companies (Ibn-Homaid \& Tijani 2015). Thus, the value engineering assessment should consider that uncertainty, risks, inflation, profit, and industry costs should be included (Ibn-Homaid \& Tijani, 2015). Value engineering assesses critical success factors of construction procurement effectiveness, project implementation, economic conditions, and government guarantees for optimum results of invested money and resource (Winter et al., 2006; Bari et al., 2012; Takim \& Akintoye, 2002). Cost modelling became the most important priority to assess money invested in projects at pre-construction stages for reaching more value of the resulted executed project. Therefore, this research found that it is mandatory to provide cost risks values to all researchers and professionals, who are working in cost modelling and estimating fields in the United Arab Emirates. The provided values will be verified and validated for direct use in future analysis. The added value to this research study because cost risks are the main driving engine of cost modelling and estimation according to latest research studies. This can solve financial management, investment decisions, and value engineering challenges.

\subsection{Problem Statement}

Researchers and professional experts face a difficulty in obtaining residential project' whole life cycle (PWLC) cost risks in the United Arab Emirates. It is challenging to collect the data and residential PWLC cost risks values are not provided in previous research. And the process is taking a long time to end with reliable and valid data. Future research and practical analysis require to have cost risks values to boost and support the expected outputs. 


\subsection{Research Aim and Significance}

This article aims to provide the first reliable and validated cost risks values of residential project' whole life cycle (PWLC) in the United Arab Emirates. The significance of this research is to provide numerical values, representing UAE project's condition, of the collected cost risks from previous literatures.

\section{RESEARCH METHODOLOGY}

This research is pure quantitative. The methodology of this research is to collect data from experts via 55 face-to-face interviews. The responding rate is $27.5 \%$ of the 200 experts' invitations. This is considered acceptable according to previous similar research in construction and built environment projects. The reliability and validity of the collected data followed, statistically, the correlation and regression modelling.

\section{DATA COLLECTION, RELIABILITY AND VALIDITY DESIGN}

This section of the research paper will detail how residential PWLC cost risks are collected and checked against the reliability and validity tests. The following parts of this section includes: (1) Data Collection Strategy, (2) Pilot Study, and (3) Experts' Competencies.

\subsection{Data Collection Strategy}

This research will combine questioner surveys with interviews to extract the most accurate data from experts in the field. In order to justify this choice, it is required to conduct a survey questioner in this research to collect and record required data, including all details (Mason, 2010). However, the required data values in the designed survey can vary based on experts' understanding.

It is also mandatory to ensure that contributors are experienced in the topic field (Tam et al., 2017). Therefore, it was required to ensure that all experts understand each variable and use their experience and knowledge to set a value for each risk. Researchers agreed that combining survey questioner with an interview forming face-to-face surveys is significantly effective and supporting data reliability (Galesic \& Bosnjak, 2009; Burns et al., 2018; Fernández et al., 2012). The following part will explain how the data collection approach has been designed to end with accurate and valid data.

To collect the required data, it is mandatory to ensure appropriate design of how to complete this process successfully (Krzywinski \& Altman, 2013; Fanning, 2005; Wang, 2010; Testa \& Simonson, 2009; Huang et al., 2015). This will ensure proceeding with appropriate analysis and reach a valid logical conclusion. This research paper will include in this part seven main stages to successfully design data collection. This will include (1) interview type, (2) interview questioner design, and (3) sample size.

\subsubsection{Interview Type}

Face-to-face interviews are proved by researchers to be the most effective, accurate, and having higher responding applicants; and it is considered as the first choice by most researchers using interviews for data collection (Forza, 2002; Filippini, 1997; Dillman et al., 2009; Trier-Bieniek, 2012; Barratt, 2012; Fernández et al., 2012; Harmeyer, 2010). This method's data can be recorded by video, voice, or survey approaches as desired (Forza, 2002; Filippini, 1997; Dillman et al., 2009; Trier-Bieniek, 2012; Barratt, 2012; Fernández et al., 2012; Harmeyer, 2010). Therefore, this research's data collection has been conducted using face-toface interviews before COVID-19 starts and because most interviewees preferred the traditional approach such as paper questionnaires and physical face-to-face interviews. 


\subsubsection{Interview Questionnaire Design}

It is compulsory to justify using questionnaire surveys and optimising its design. Surveys are an extremely useful and powerful tool to obtain information (Glasow, 2005). It is essential to design the survey format to optimize information extraction from respondents (Glasow, 2005; Fanning, 2005). This targets a smooth questionnaire with less confusion and an acceptable length (Herzog \& Bachman, 1981). Paper questionnaires have several advantages, such as (1) the ability to ensure that the desired audience fills the questionnaire, (2) the ability to write notes on papers back, and (3) the ability to conduct the task in any place without technologies constraints and requirements. The disadvantages of paper questionnaires are including the additional costs to cover a wide geographical area and the sustainability impact (Yusof et al., 2016). However, this research study uses recyclable papers to cover collecting information and data from the United Arab Emirates, only with no additional costs. So, the disadvantages of paper questionnaires have no negative impact on this research study.

The survey questioner design in this research study has followed the optimum design requirements and format according to researchers' recommendations to maximize the smoothness of data collection without fail or difficulties as the following (Fanning, 2005; Glasow, 2005; Herzog \& Bachman, 1981; Hoddinott \& Bass, 1986; Galesic \& Bosnjak, 2009).

- The cover page includes the study intentions and questions answering directions.

- Figures and charts have been used to facilitate answering all questions within a short time. This research study gives interviewees the ability to answer three questions by providing one answer (i.e., risk, probability, and impact matrix).

- The factor-grouping method is used for better understanding to avoid respondents' confusion and to answer questions accurately.

- The questionnaire presented all risks in a table to facilitate shifting between questions without getting lost.

- The respondents designed the questionnaire to answer each question with one number chosen from the provided risk matrix. This will significantly reduce the required time for answering all questions (i.e., 117 cost risks/variables).

Next, this research uses the Project Management Institute (PMI) to have the right weight for each risk probability and its impact. PMI is involved in project management research and development. The original PMI risk matrix is divided into two impacts (i.e., Threats and Opportunities). This can create confusion for the data providers (i.e., experts).

Therefore, the PMI original risk matrix's required adjustment, as shown in Figure 1. The adjustment is based on having threats and opportunities in one impact matrix instead of two. This will make it easier to put the absolute risk value based on its impact and probability without thinking about its negative or positive sign. The final modelling process will classify threats and opportunities based on mathematical modelling outputs signs (i.e., positive and negative).

Finally, the used matrix in the face-to-face interview questionnaires needed experts to focus only on the probability and impact numbers of each risk factor. Color can be a source of distraction and/or a second approach to provide answers. Therefore, this research questionnaire decided to remove the colors from the final used questionnaire, as shown in Figure 2. 


\begin{tabular}{|c|c|c|c|c|c|c|}
\hline \multicolumn{7}{|c|}{$\begin{array}{c}\text { Project Management Institute (PMI) Risk Matrix: } \\
\text { Probability X Impact }\end{array}$} \\
\hline \multirow{5}{*}{ 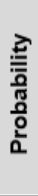 } & $90 \%$ & $5 \%$ & $9 \%$ & $18 \%$ & $36 \%$ & $72 \%$ \\
\hline & $70 \%$ & $4 \%$ & $7 \%$ & $14 \%$ & $28 \%$ & $56 \%$ \\
\hline & $50 \%$ & $3 \%$ & $5 \%$ & $10 \%$ & $20 \%$ & $40 \%$ \\
\hline & $30 \%$ & $2 \%$ & $3 \%$ & $6 \%$ & $12 \%$ & $24 \%$ \\
\hline & $10 \%$ & $1 \%$ & $1 \%$ & $2 \%$ & $4 \%$ & $8 \%$ \\
\hline & & $5 \%$ & $10 \%$ & $20 \%$ & $40 \%$ & $80 \%$ \\
\hline & & \multicolumn{5}{|c|}{ Impact } \\
\hline
\end{tabular}

Figure 1. Adjusted colored Project Management Institute (PMI) Risk Matrix.

\begin{tabular}{|c|c|c|c|c|c|c|}
\hline \multirow{5}{*}{$\begin{array}{l}\frac{2}{2} \\
\frac{2}{0} \\
\frac{0}{10} \\
0 \\
0 \\
0\end{array}$} & $90 \%$ & $5 \%$ & $9 \%$ & $18 \%$ & $36 \%$ & $72 \%$ \\
\hline & $70 \%$ & $4 \%$ & $7 \%$ & $14 \%$ & $28 \%$ & $56 \%$ \\
\hline & $50 \%$ & $3 \%$ & $5 \%$ & $10 \%$ & $20 \%$ & $40 \%$ \\
\hline & $30 \%$ & $2 \%$ & $3 \%$ & $6 \%$ & $12 \%$ & $24 \%$ \\
\hline & $10 \%$ & $1 \%$ & $1 \%$ & $2 \%$ & $4 \%$ & $8 \%$ \\
\hline & & $5 \%$ & $10 \%$ & $20 \%$ & $40 \%$ & $80 \%$ \\
\hline
\end{tabular}

Figure 2. Final Adjusted Project Management Institute (PMI) Risk Matrix: Probability and Impact Matrix.

\subsubsection{Questions Type}

In this research study, the structured interview is based on collecting specific data related to listed factors and variables (Reja et al., 2003). It is optimum to control collected answers with close-ended questions (Reja et al., 2003). In this research study, each question offers to select from a range of multiple choices (Reja et al., 2003). This is to ensure extracting accurate information after utilizing experts' experience to serve this study. Table 1 shows how this research study satisfied researchers developed questionnaire questions analysis guidelines (Makienko \& Bernard, 2012, p.143).

Table 1. Adapted Questionnaire Questions Analysis Criteria against this research study Questions Design (Makienko \& Bernard, 2012, p.143).

\section{Questionnaire Questions Analysis Criteria}

1. "Based on the survey questions, what is its main goal?"

2. What main construct (dependent variable) this study is trying to measure?

3. "What other constructs is the survey trying to measure"?

4. "Do scales capture all domains of the main construct (main dependent variable)?'

5. "How many open-ended vs close-ended questions are in the survey? Are there too many open-ended questions?"

6. "Are there any duplicate/unnecessary questions?"

7. “Are questions clear and easy to understand?"

8. "Are there any sensitive questions?"

9. "Is the survey too long or too short?"

10. "Does the survey use the best format/layout?"

11. Does the survey use the appropriate letter size?

12. What research questions can be answered by analysing this survey?

13. What types of statistical analyses can be run based on available independent and dependent variables?

\section{This research Study Questions Design}

To collect the required data used to build projects' whole lifecycle final cost model.

This study is trying to measure the cost risk value in the United Arab Emirates.

This study is trying to measure cost risks impact and occurrence probability in the UAE.

Yes, the given scale is based on the Project Management Institute PMBOK guideline

All questions are closed-no open questions.

No, it has been insured through multiple revisions.

Very Clear, and the researcher will be available as an interviewer to clear any doubts.

No. All sensitive questions are considered optional after the pilot study.

It is considered long (i.e., $45 \mathrm{~min}$ ). However, after the pilot study, it can be completed in more than one session.

Yes, following researchers' optimum guidelines.

Yes, (Time New Roman) Font 12. No negative feedback was found about font during the pilot study.

It will answer directly research question 1 , and it is mandatory to answer research questions 2 and 3 .

Correlation and regression statistical analysis. 


\subsubsection{Sample Size}

Determining the sample size in the research data collection stage is mandatory and critical for statistical analysis (Cai \& Hames, 2011).

Although there is no clear specific justification of setting a fixed certain significance level (i.e., precision level) other than what is followed in statistical traditions according to researchers and published articles (Trafimow et al., 2018; Brunnström \& Barkowsky, 2018; Pérez \& Pericchi, 2014). The most common significance levels in the quantitative statistical research approach are usually $95 \%$ (Trafimow et al., 2018; Brunnström \& Barkowsky, 2018; Pérez \& Pericchi, 2014). This research study is going to set the significance level as $95 \%$ (i.e., $1-\alpha=1-0.05=0.95$ ). This decision's validity will be clearer after knowing that previous research and publications proved that changing $\alpha$ from 0.05 to 0.005 makes no difference in the discussion and conclusion of any binary numerical system study (Trafimow et al., 2018; Brunnström \& Barkowsky, 2018; Pérez \& Pericchi, 2014).

Previously published research studying construction factors and risks used 200 invitation sample size (Vidogah \& Ndekugri, 1998). The valid responding percentage from all invited 200 experts was 27\% (Vidogah \& Ndekugri, 1998). Researchers also found that after inviting 218 listed cost experts Royal Institute of Chartered Surveyors (RICS), the valid response rate increased to 31\% (Elhag et al., 2005). On the other hand, the valid response rate was found equal to $30.5 \%$ of 285 invited construction experts in other similar studies of this research (Aziz \& Abdel-Hakam, 2016). Moreover, in other construction factors literature, the higher invited sample is not necessarily increasing the responding rate percentage; for example, it was found that only $28.3 \%$ responded after inviting 300 contractors' top management (i.e., experts) to answer questionnaires related to construction factors (Shash, 1993). Published literature declared that most construction research studies invited 200 experts from the industry to answer their questionnaire and received back 20-30\% of their 200 invitations (Akintoye \& Fitzgerald 2000). These research considered this percentage range a valid criterion to accept the collected data in similar research studies (Akintoye \& Fitzgerald, 2000). However, it is proved by previous research that increasing invitation-sample size, to include more than 200, has no considerable impact on responding rate percentages (i.e., acceptance criterion). The agreed acceptable responding rate percentage has been found between $20 \%$ to $31 \%$ of sent invitation quantities. Therefore, this research study sent invitations to 200 experts randomly. So, the acceptable sample size is expected to be between 40 (i.e., 20\% of 200) to 62 (31\% of 200) random samples. It will be covering the minimum requirements of quantitative statistical analysis (i.e., at least 29). This research has completed 55 face-to-face interview questionnaires with experts. The resulting responding percentage has been found $27.5 \%$, almost within the top $90 \%$ of other similar studies' acceptable percentages. Therefore, this research study is approved, and the valid sample size is 55 face-to-face experts' interview questionnaires.

\subsection{Pilot Study}

A pilot study is essential in any research data collection to identify a good sample size; however, it is also essential to identify possible challenges and improvements (Ruiz et al., 2017; Toor \& Ogunlana, 2009; Aziz \& Abdel-Hakam, 2016; Viechtbauer et al., 2015). Determining the pilot study sample size can be using the "role of thumb" or by calculating it mathematically (Cocks \& Torgerson, 2013, p.199; Kraemer et al., 2006). Nevertheless, based on the researchers' recommendations of similar studies, the pilot study sample size has been decided to equal 5\% (i.e., 1 pilot sample of each desired 20 main samples) to optimize the results (Viechtbauer et al., 2015). Therefore, the pilot study has been decided to be 3 (i.e., between $1.5 \approx 2$ and $3.1 \approx 3$ pilot samples) based on the chosen main sample size (i.e., 40 to 62 ). To ensure a valid pilot 
sample size, further literature has been reviewed to support the chosen pilot sample. For example, similar research selected six samples for a pilot study representing 117 main sample sizes, including interviews and questionnaires (Aziz \& Abdel-Hakam, 2016). This is equal to about 5\% (i.e., 6/117=5.1\%); however, the sample range was between 87 and 118 (i.e., 20\% to $31 \%$ respond rate). Therefore, it is acceptable. Another similar study selected 6 pilot samples to represent the expected 115 main sample size (Toor \& Ogunlana, 2009). However, the research ended with having six pilot samples representing 111 main sample sizes, including interviews and questionnaires (Toor \& Ogunlana, 2009). This pilot percentage has shifted from 5.2\% (i.e., 6/115) to 5.4\% (i.e., 6/111), which is approximately 5\%, and the actual main sample did not exceed the range higher limit. Other quantitative research selected 12 pilot samples to represent 230 main validation samples (Ruiz et al., 2017). This result was found equal to $5.2 \% \approx 5 \%$. Therefore, it is acceptable to consider this research study piloting sample equal to 3 (i.e., $5 \%$ ); however, the main sample size did not exceed the higher limit (i.e., $55<62$ ).

After improving the questionnaire and identifying all possible challenges, it is essential to consider this study's face-to-face interview questionnaire's final duration. The final validated questionnaire requires 45 minutes to be completed. To validate this duration, it is mandatory to review previous research literature. So, researchers declared an interview could take 30 minutes up to several hours (DiCicco-Bloom \& Crabtree, 2006). The United States Census Bureau concluded that each in-person interview questionnaire takes between 25 and 75 minutes (Bogen, 1994). Nevertheless, other researchers proved that most questionnaires have a duration of 10, 15, 20, and 30 minutes (Galesic \& Bosnjak, 2009; Barnes, 2001). This is significant in maintaining the quality of collected data and maintaining a higher responding rate (Galesic \& Bosnjak, 2009; Barnes, 2001). Therefore, this research study has an acceptable face-to-face interview questionnaire duration (i.e., 45 minutes). It maintains the quality of data collection and responding rate by offering an optional choice to complete the questionnaire in more than one session. This will ensure that all collected data in one session is not rushed and by interviewees choice. Moreover, it will ensure that busy interviewees' data collection quality (i.e., construction industry experts) is maintained as required.

\subsection{Experts' Competencies}

Data collection in this research methodology design is based on 200 residential building project's whole life cycle experts' invitations. From previous similar studies (i.e., real estate development and construction project management), experts who have a related knowledge base and who have similar projects experience were used to provide acceptable data for research studies, including cost and duration variables (Zimmermann \& Eber, 2017). Previous similar studies (i.e., buildings predictive maintenance criteria) accepted experts' evaluations to draw a valid scientific research conclusion (Zimmermann \& Eber, 2017). However, it is important to define experts and ensure that data providers for this research are valid and are satisfying the designed research methodology. According to the literature, choosing data collection experts is to "excellence" level of requested outputs (Mieg, 2009, p.92). Traditionally, researchers defined experts as people who can evaluate something better than anyone else because they know more than others in their specific knowledge (Zimmermann \& Eber, 2017). Also, experts' outputs are termed in literature as the "road to excellence" (Mieg, 2009, p.92). Researchers stated that assessment excellence in scientific research is the output of true expertise (Mieg, 2009). As a result, it is essential to understand the criteria of experts' considerations for scientific studies (Mieg, 2009; Zimmermann \& Eber, 2017; Flores-Colen et al., 2010). This is significant to ensure experts' assessment excellence level (Mieg, 2009). Commonly, experts' evaluation validity is justified by reputation (Zimmermann \& Eber, 2017). This reputation is called experience (Zimmermann \& Eber, 2017). The experience is defined as the satisfactory number of successful 
similar systems investigations to reach the ability to predict complex systems' behaviour and estimate variables' values within acceptable small margins (Zimmermann \& Eber, 2017). In this research study, it is required to be more specific in identifying experts. First, from reviewed literature, the "10-year rule" requirement stated that experts need to study the area of knowledge for 10,000 to 50,000 hours before considering their reputation (i.e., expertise) (Mieg 2009, p.93). This is equal between 3.5 to 17 years based on 8 hours per day to reach maters level (Mieg, 2009). From another perspective, it is equal to 4.8 to 24 years of studying the knowledge based on 40 hours a week and 52 weeks a year. In similar studies (i.e., built environment), researchers conducted and accepted 30 expert survey questionnaires; however, the experts' selection approach included two main criteria (Mieg, 2009). The first criterion is a higher education qualification (Mieg, 2009). It required a minimum of 5-years of university degree qualification (Mieg, 2009). The second criterion is the number of years of specialized experience in addition to a university degree qualification (Mieg, 2009). Researchers classified experts with 5-year degree qualification plus 2 to 7 years of related specialized experience as high experts (Mieg, 2009). On the other hand, they classified experts who have only a 5-year degree qualification, with high sensitivity to the research topic, as medium experts (Mieg, 2009). Therefore, this research study considers high experts as professionals with 5-year degree qualification and at least two years of related specialized experience. Moreover, considering medium experts as professionals with a 5-year degree qualification in engineering related to building environment knowledge (i.e., construction and operation) such as civil engineering, mechanical engineering, electrical engineering, construction engineering, and facilities engineering. Due to the large cultural and educational diversity in the United Arab Emirates, this research targeted only experts registered in built environment organizations (i.e., contractors, consultants, developers, and government). It is because the Ministry of Human Resources and Emiratization (i.e., Ministry of Labor) in the United Arab Emirates ensure the authenticity of degree certificates before issuing work permits and does not register engineers' contracts unless the licensing authorities approve them (i.e., Abu Dhabi Municipality and Society of Engineers). This will ensure selecting valid experts who satisfy the minimum acceptable conditions, including authentic equivalated 5-year engineering degree qualification and approved relevant specialized experience as shown in figure 1 . This research study invited 200 experts following the previous justified criteria and completed 55 face-to-face survey interviews within acceptable response rate (i.e., 27.5\%).

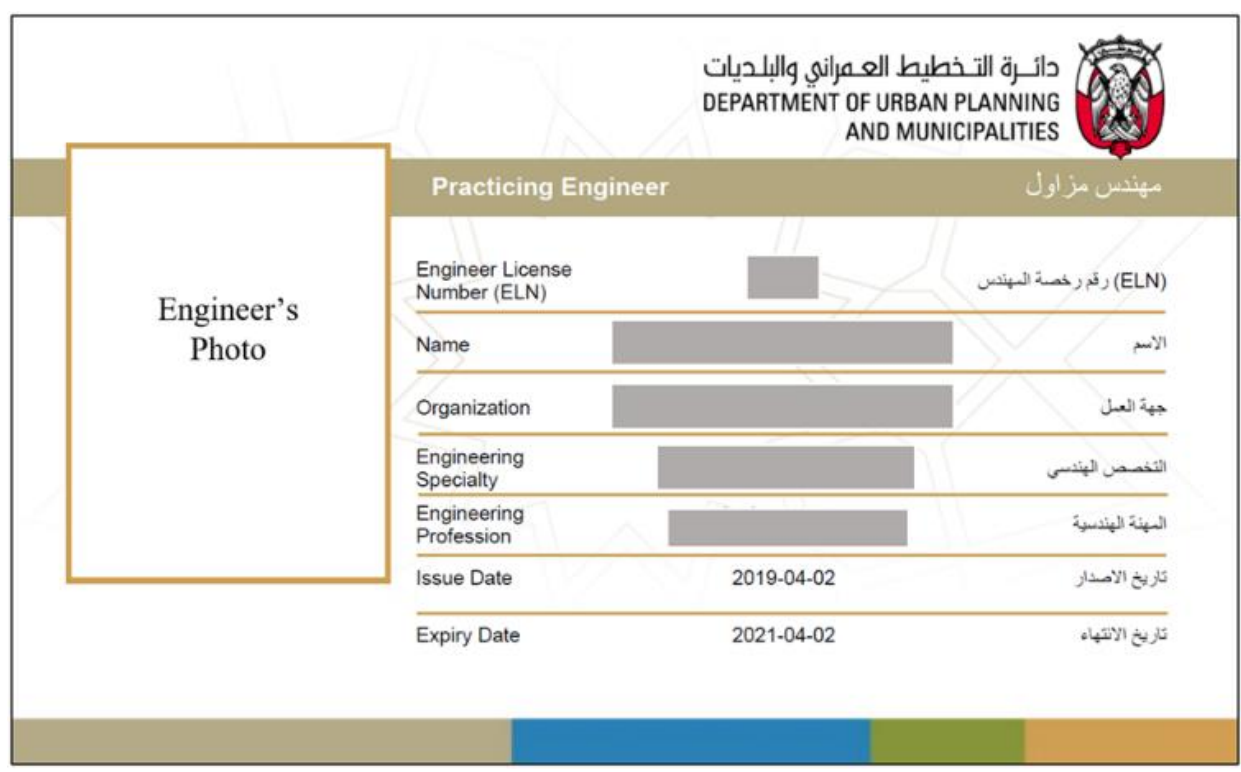

Figure 3. Abu Dhabi Municipality License Sample to show official provided information to validate experts. 


\section{RELIABILITY AND VALIDITY RESULTS}

Correlation and regression analysis results will be detailed in the following parts to end with validated data (i.e., cost risks values). It is including (1) Data Correlation Analysis and (2) Data Regression Analysis.

\subsection{Data Correlation Analysis}

Correlation is defined as the measurement of a specific pattern of association (West et al., 2013). However, the association occurs when a scatterplot takes a pattern between two numerical variables (West et al., 2013). After validating data providers' ability to contribute to this research study, three types of essential reliability criteria need to be satisfied. First, the statistical significance test of quantitative results is deciding the repeatability or replicability of these results during a particular period (Golafshani, 2003). This is the indicator of data strength. In correlation analysis, P-Value is the significance of hypothesis consideration. Second, measurement stability is an important type for testing quantitative results reliability (Golafshani, 2003).

This means that stable measurements over time are more reliable than unstable measurements (Golafshani, 2003; Rungtusanatham et al., 2003; Sauro \& Lewis, 2012; Mohd et al., 2015). Stability (i.e., strength) can be defined as the correlation between 2 separate readings of the same subject (Vanderwal et al., 2021). Third, the similarity type of reliability can be defined as the average correlation of readings within a given condition (Vanderwal et al., 2021;). Correlation R-values range between +1 and -1 (Ratner, 2009; DeSoto \& Roediger, 2014). In correlation analysis, the r-value is the scatter strength and similarity indicator. The considered hypotheses for this research correlation analysis are listed as the following:

Let, $\rho$ represent the Correlation of Pearson Population, then

Ho: $\rho=0$, (i.e., No Correlation between variables),

$\mathrm{H}_{\mathrm{I}}: \quad \boldsymbol{\rho} \neq 0$, (i.e., Correlation is available between variables)

$\mathrm{HO}$ is true if the significance does not exist (i.e., $\mathrm{P}$-value $>0.05) . \mathrm{H}_{\mathrm{I}}$ is true if correlation analysis showed significance P-value $\leq 0.05$. This research is conducting all statistical analysis using the SPSS software program.

As shown in the appendix correlation table, Linear Relationship Strength columns showed color coding representing correlation analysis $p$-value and the $r$-value. The $p$-value significance has been discussed earlier. However, it is important to understand the r-value representation. Although there is no specific rule for considering linear relationship classifications, this research has created the most appropriate based on reviewed literature.

According to literature reviews, there is no linear relationship between data scatters if there is no significance (Ratner, 2009; Schober et al., 2018). However, a linear relationship exists if hypothesis HI is true $(\rho \neq 0)$ based on $p$-value $\leq 0.05$ (Ratner, 2009; Schober et al., 2018). $\mathrm{H}_{\mathrm{I}}$ hypotheses will have a correlation analysis $r$-value between 0 and 1 for positive relationships and if correlation analysis $r$-value is between 0 and -1 for negative relationships (Ratner, 2009; Schober, Boer \& Schwarte, 2018). It is weak if the r-value is between 0 to 0.3 and within (0) to (-0.3) (Ratner, 2009). It is moderate if the r-value is within 0.3 to 0.7 and within (-0.3) to (-0.7) (Ratner 2009). Table 2 summarizes how Ratner (2009) classified linear data relationships based on Pearson's correlation coefficient r-value. It is strong if the r-value is within 0.7 to 1 and within (-0.7) to (-1) (Ratner 2009). 
Table 2. summarize how Ratner (2009) classified data linear relationships based on "Pearson's correlation coefficient" $r$-value.

\begin{tabular}{cc}
\hline Pearson's correlation coefficient r-value & Linear Relationship Classification \\
\hline $\begin{array}{c}\text { P-Value }>0.05 \\
0 \text { to } 0.3 \text { and } 0 \text { to }-0.3\end{array}$ & No linear relationship \\
0.3 to 0.7 and -0.3 to -0.7 & Weak linear relationship \\
0.7 to 1 and -0.7 to -1 & Strong linear relationship \\
\hline
\end{tabular}

Other researchers have included more than 3 classifications, as shown in Table 3 (Schober, Boer \& Schwarte 2018). It is including 5 strength classifications of linear relationships (Schober, Boer \& Schwarte 2018).

Table 3. summarize how Schober, Boer and Schwarte (2018) classified data linear relationships based on Pearson's correlation coefficient r-value.

\begin{tabular}{cc}
\hline Pearson's correlation coefficient r-value & Linear Relationship Classification \\
\hline $\begin{array}{c}\text { P-Value }>0.05 \\
\text { No significance }\end{array}$ & No linear relationship \\
0 to 0.1 and 0 to -0.1 & Weak linear relationship \\
0.1 to 0.39 and -0.1 to -0.39 & Moderate linear relationship \\
0.4 to 0.69 and -0.4 to -0.69 & Strong linear relationship \\
0.7 to 0.89 and -0.7 to -0.89 & Very Strong linear relationship \\
0.9 to 1 and -0.9 to -1 & \\
\hline
\end{tabular}

Previous cash flow literatures divided correlation strength based on weak (i.e., $0 \%$ to $33 \%$ ), average (i.e., $34 \%$ to $66 \%$ ), strong (i.e., $67 \%$ to $90 \%$ ), and very-strong (i.e., $91 \%$ to $100 \%$ ) (Konior \& Szóstak, 2020).

Therefore, this research study created its most suitable linear relationship strength classifications, including color coding and justification remarks, based on the previously reviewed literature, as shown in table 4.

The validity of quantitative research is based on the final useability and accuracy (Golafshani, 2003; Almquist et al., 2014). According to positivists, validity can be quantified based on testing the mathematical and measurement models to check if the research outputs can measure what it is intended to measure (Golafshani, 2003).

This research ensured to include most of its data reliability stability as strong as possible. Therefore, this stage is assumed valid for further analysis in regression modelling as per literature recommendation (i.e., a correlation exists) (Ratner, 2009; Schober et al., 2018). 
Table 4. Color coding of data linear relationships based on Pearson's correlation coefficient $r$-value.

\begin{tabular}{|c|c|c|}
\hline Pearson's correlation coefficient r-value & $\begin{array}{c}\text { Linear Relationship } \\
\text { Classification /Color coding }\end{array}$ & Remarks \\
\hline $\begin{array}{l}\text { P-Value }>0.05 \\
\text { (No significance) } \\
\text { And within } \\
(0) \text { to }(0.3>) \text { and } \\
(0) \text { to }(-0.3>) \\
\end{array}$ & No linear relationship & $\begin{array}{l}\text { This is because researchers agreed that there is no relationship } \\
\text { if there is no significance and the relationship is neglectable or } \\
\text { very weak within }(0) \text { to }(0.3>) \text { and }(0) \text { to }(-0.3>)\end{array}$ \\
\hline $\begin{array}{l}(0.3 \geqslant) \text { to }(0.5>) \text { and } \\
(-0.3 \geqslant) \text { to }(-0.5>)\end{array}$ & Weak linear relationship & $\begin{array}{l}\text { There is a debate about considering moderate linear } \\
\text { relationships if } r \text {-value is between } 0.3 \text { to } 0.4 \text {. } \\
\text { So, this research is considering r-values within } \\
(0.3 \geqslant) \text { to }(0.5>) \text { and } \\
(-0.3 \geqslant) \text { to }(-0.5>) \\
\text { as weak linear relationships }\end{array}$ \\
\hline $\begin{array}{l}(0.5 \geqslant) \text { to }(0.7>) \text { and } \\
(-0.5 \geqslant) \text { to }(-0.7>) \\
(0.7 \geqslant) \text { to }(1) \text { and } \\
(-0.7 \geqslant) \text { to }(-1)\end{array}$ & Moderate linear relationship & $\begin{array}{l}\text { All reviewed literatures agreed on that } r \text {-values within } \\
(0.7 \geqslant) \text { to }(1) \text { and } \\
(-0.7 \geqslant) \text { to }(-1) \\
\text { is strong linear relationships. So, this research is considering } \\
\text { moderate linear relationship for r-values within } \\
(0.5 \geqslant) \text { to }(0.7>) \text { and } \\
(-0.5 \geqslant) \text { to }(-0.7>)\end{array}$ \\
\hline
\end{tabular}

\subsection{Data Regression Analysis}

The final step in validating experts collected data is the regression analysis. The stability-similarity relationship is conducted based on the significance P-Value between the dependent variable with each of its independent variables (Vanderwal et al., 2021; Golafshani, 2003). This research is approaching stabilitysimilarity relationship by ensuring the significance between risks and their impacts/probabilities as shown in the appendix regression table. Linear regression analysis will be conducted for each risk variable using SPSS software to satisfy equation 1 and Table 5. This will include the risk's value as a dependent variable, while the independent variables will impact its probability values.

$$
\boldsymbol{Y}=\boldsymbol{\beta}_{0}+\boldsymbol{\beta}_{\text {prob }} \boldsymbol{X}_{\text {prob }}+\boldsymbol{\beta}_{\text {imp }} X_{\text {imp }}+\xi
$$

$\mathbf{Y}=$ the Risk dependent Variable of each factor.

Xprob \& Ximp = the probability and impact independent Variable of each factor.

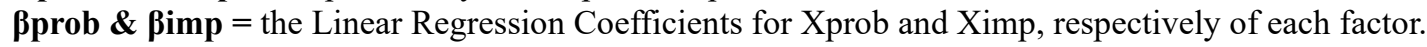

$\xi=$ the Error (Equal Zero because it is not time-based).

Table 5. Regression Mandatory Error Assumptions Validation Requirements (Kadiyala, 1970; Nazif et al., 2016; Jafarzadeh et al., 2015).

\footnotetext{
Regression Mandatory Error Assumptions Validation Requirements

1. The error's probability distribution of the regression should be normally distributed (i.e., Bell-shaped).

2. The error's population mean value $(\mu \varepsilon)$ must equal to zero.

3. The error's variance ( $\delta 2)$ must be constant for all independent $\mathrm{X}$ values

4. The errors must be independent for all dependent $Y$ values
} 
The appendix regression table has multiple color coding for two columns (i.e., R-Square and Number of Outliers columns) as explained in Table 6. It is important to highlight outliers to track the minimum acceptable data sample size. Therefore, there are four color codes under the (Number of Outliers) column. The minimum acceptable sample response rate was concluded from literature is 40 response out of 200 invitations (Akintoye \& Fitzgerald, 2000; Vidogah \& Ndekugri, 1998; Elhag et al., 2005; Shash, 1993). This research has completed 55 face-to-face survey interviews. So, the optimum scenario is to use all 55 samples in the final regression model.

It is then important to understand the meaning of the R-Square value in regression analysis and classify its readings. According to researchers, R-Square should be analyzed using the goodness of fitness (i.e., GOF) approach (Petroutsatou \& Lambropoulos, 2010). This approach states that a regression model's RSquare has an acceptable percentage if the goodness of fitness measure meets the required criteria (Petroutsatou \& Lambropoulos, 2010). R-Square's criterion is to have acceptable goodness of fitness index (i.e., GFI) ratio (Petroutsatou \& Lambropoulos, 2010). This ratio is based on considering R-Square values from zero to one (Petroutsatou \& Lambropoulos, 2010). The model is considered not fit and does not represent the sampled population if the GFI ratio equal to zero (Petroutsatou \& Lambropoulos, 2010). The model is a perfect fit if the GFI ratio is equal to one (Petroutsatou \& Lambropoulos, 2010). Researchers consider the R-Square value is the goodness of fit index ratio (Petroutsatou \& Lambropoulos, 2010). The acceptable recommended criterion set by previous literature is to have R-Square (i.e., GFI) $\geq 80 \%(0.80)$ (Petroutsatou \& Lambropoulos, 2010). Only one risk (i.e., concessionaire's inability) had an R-Square value of less than $80 \%$ (i.e., 63.2\%), as shown in the appendix regression table. According to researchers, this issue required deeper investigation because it is an essential cost risk (Alzahrani, 2015; Trangkanont \& Charoenngam, 2013). It is also found that researchers in previous housing cost risks modelling literature declared that the concessionaire's inability must be assigned to the private organization (Trangkanont \& Charoenngam, 2013). This cost risk shall be included in the final cost estimation model because this research study includes all client types. It is recommended to conduct future research about this risk value using the private sector's experts in the UAE.

Table 6. Regression analysis color coding criteria used.

\begin{tabular}{|c|c|c|}
\hline Column & Color coding criteria & Column \\
\hline Number of Outliers & No Color $=$ Zero outliers & Full collected sample is used \\
\hline Number of Outliers & $13 \geq$ Outliers $\neq$ Zero & $\begin{array}{c}\text { Minimum acceptable sample response }=42 \\
42 \leq \text { Sample size }\end{array}$ \\
\hline Number of Outliers & $13<$ Outliers $\neq$ Zero $\leq 25$ & $\begin{array}{l}\quad 30<\text { Sample size }<42 \\
\text { (Color code criterion has not been met) }\end{array}$ \\
\hline Number of Outliers & $\mathbf{2 5}<$ Outliers $\neq$ Zero & $\begin{array}{l}\qquad 30>\text { Sample size } \\
\text { (Color code criterion has not been met) }\end{array}$ \\
\hline R-Square & R-Square $<\mathbf{8 0} \%$ & Only 1 found \\
\hline R-Square & $80 \leq$ R-Square $<90 \%$ & - \\
\hline R-Square & R-Square $>90 \%$ & - \\
\hline
\end{tabular}

Durbin-Watson's value is ranging from 0 to 4 (Nazif et al., 2016; Jafarzadeh et al., 2015). However, according to researchers, it is important to keep the Durbin-Watson value as close as possible to 2 (i.e., complete avidness of autocorrelation) (Nazif et al., 2016; Jafarzadeh et al., 2015). It is impossible to have data Durbin-Watson exactly equal to 2 (Nazif et al., 2016; Jafarzadeh et al., 2015). However, it can be as 
close as possible to be considered autocorrelation with no-impact or neglectable impact on data sets (Nazif et al., 2016; Jafarzadeh et al., 2015). Mathematically, values above 1.5 can be approximated to 2 (i.e., $X \approx$ 2 , if $X>1.5$ ). And values below 2.5 can be approximated to 2 (i.e., $X \approx 2$, if $X<2.5$ ). Therefore, the outliers had to be removed to keep the Durbin-Watson value between 1.5 to 2.5 (i.e., $1.5<$ Durbin-Watson $<2.5$ ) for avoiding any autocorrelation within the analysis results (Nazif et al., 2016; Jafarzadeh et al., 2015).

\section{CONCLUSION AND RECOMMENDATION}

To sum up, this article identified and validate 117 cost risks values for residential project's whole life cycle. The process of data collection, analysis, and validation has been discussed including (1) data collection strategy, (2) experts' competencies, (3) data correlation analysis, and (4) data regression analysis.

\subsection{Originality}

According to the best knowledge of the author, there is no previous research identified reliable and valid residential project's whole life cycle cost risks values in the United Arab Emirates.

\subsection{Theoretical Implications}

The outputs of this article can by used in a wide range of quantitative analytical project management research which is related to residential projects' cost and risk modelling. Also, the used approach can be utilized to identify the values of cost risks of other projects types in many regions.

\subsection{Practical Implications}

Project management professionals can us the output of this research as an initial risk value for each identified risk. Then, they can use the regression equation of each risk to update the risks over the project time based on the changes happening in the risk's impact/probability.

\subsection{Limitations and Future Research Recommendations}

The following limitations are highlighted for future research consideration:

1. The collected data was based on experts' face-to-face survey interviews. It is recommended to investigate the model response after using different sample size for data collection.

2. This research developed the final model for residential projects WLC including all private, public, and public-private projects' experts together to collect data risk values. This caused an argument, to the inability-to-concessionaire risk. The risk proved essential for building construction projects except that it is clearly mentioned in a PPP (i.e., public-private-projects) study to allocate inability to concessionaire risk to private projects only. This research has justified its data because most of the chosen experts are from the public sector. Therefore, future research is recommended to investigate distinguishing between private, public, and public-private residential projects when collecting data from experts.

3. These research outputs (i.e., system dynamics PWLC cost modelling) is restricted to residential projects in the United Arab Emirates. This is because it is built, validated, and verified using the UAE residential project industry's data solely. It is recommended to investigate cost risks values of other different project's types, including residential buildings (excluding in UAE), hotel buildings, commercial buildings, industrial buildings, and infrastructure projects. Each project type study can be done in many regions. 


\section{REFERENCES}

[1] Akintoye, A. and Fitzgerald, E. (2000). A survey of current cost estimating practices in the UK, Construction Management and Economics, vol. 18(2), pp. 161-172.

[2] Almquist, Y. B., Ashir, S. and Brännström, L. (2014). A guide to quantitative methods: study suide. Sweden: Stockholm University.

[3] AlMazrouei, H. and Pech, R. J. (2015) 'Working in the UAE: expatriate management experiences', Journal of Islamic Accounting and Business Research, vol. 6(1), pp. 73-93. doi: 10.1108/JIABR-08-2013-0032.

[4] Alzahrani, S (2015). Dynamic Simulation of the Impact of Risk Events and Risk Cost in KSA PPP Projects. PhD Thesis. Liverpool, UK: University of Liverpool, Faculty of Engineering.

[5] Aziz, R. F. and Abdel-Hakam, A. A. (2016). Exploring delay causes of road construction projects in Egypt, Alexandria Engineering Journal, vol. 55(2), pp. 1515-1539.

[6] Barratt, M. J. (2012). The efficacy of interviewing young drug users through online chat, Drug and Alcohol Review, vol. 31(4), pp. 566572 .

[7] Bari, N. A. A., Yusuff, R., Ismail, N., Jaapar, A. and Ahmad, R. (2012). Factors Influencing the Construction Cost of Industrialised Building System (IBS) Projects, Procedia - Social and Behavioral Sciences, vol. 35(12), pp. 689-696.

[8] Bogen, K. (1994). THE EFFECT OF QUESTIONNAIRE LENGTH ON RESPONSE RATES -- A REVIEW OF THE LITERATURE, U.S. Bureau of the Census.

[9] Brunnström, K. and Barkowsky, M. (2018). Statistical quality of experience analysis : on planning the sample size and statistical significance testing, Journal of Electronic Imaging, vol. 27(5), pp. 1-11.

[10] Burns, E., Prigerson, H. G., Quinn, S. J., Abernethy, A. P. and Currow, D. C. (2018). Moving on: Factors associated with caregivers' bereavement adjustment using a random population-based face-to-face survey, Palliative Medicine, vol. 32(1), pp. $257-267$.

[11] Cai, Y. and Hames, D. (2011). Minimum sample size determination for generalized extreme value distribution, Communications in Statistics - Simulation and Computation, vol. 40(1), pp. 87-98.

[12] Cocks, K. and Torgerson, D. J. (2013). Sample size calculations for pilot randomized trials: a confidence interval approach, Journal of Clinical Epidemiology, vol. 66(2), pp. 197-201.

[13] DeSoto, K. A. and Roediger, H. L. (2014). Positive and Negative Correlations Between Confidence and Accuracy for the Same Events in Recognition of Categorized Lists, Psychological Science, vol. 25(3), pp. 781-788.

[14] DiCicco-Bloom, B. and Crabtree, B. F. (2006). The qualitative research interview, Medical Education, vol. 40(4), pp. $314-321$.

[15] Dillman, D. A., Phelps, G., Tortora, R., Swift, K., Kohrell, J., Berck, J. and Messer, B. L. (2009). Response rate and measurement differences in mixed-mode surveys using mail, telephone, interactive voice response (IVR) and the Internet, Social Science Research, vol. 38(1), pp. 1-18.

[16] Elhag, T. M. S., Boussabaine, A. H. and Ballal, T. M. A. (2005). Critical determinants of construction tendering costs: Quantity surveyors' standpoint, International Journal of Project Management, vol. 23(7), pp. 538-545.

[17] Fanning, E. (2005). Formatting a Paper-based Survey Questionnaire: Best Practices, A peer-reviewed electronic journal, vol. 10(12), pp. $1-14$.

[18] Fernández, E. A., Igúzquiza, V. D. de R., Lautre, I. G. and Calvo, I. L. (2012). Face to face and telephone surveys in terms of sampling representativeness: a multidimensional analysis, Qual Quant, vol. 46(1), pp. 303-313.

[19] Filippini, R. (1997). Operations management research: Some reflections on evolution, models and empirical studies in OM, International Journal of Operations \& Production Management, vol. 17(7-8), p. 655-670.

[20] Flores-Colen, I., de Brito, J. and Freitas, V. (2010). Discussion of Criteria for Prioritization of Predictive Maintenance of Building Façades: Survey of 30 Experts, Journal of Performance of Constructed Facilities, vol. 24(4), pp. 337-344.

[21] Forza, C. (2002). Survey research in operations management: a process-based perspective, International Journal of Operations \& Production Management, vol. 22(2), pp. 152-194.

[22] Galesic, M. and Bosnjak, M. (2009). EFFECTS OF QUESTIONNAIRE LENGTH ON PARTICIPATION AND INDICATORS OF RESPONSE QUALITY IN A WEB SURVEY, Oxford University Press on behalf of the American Association for Public Opinion Research, vol. 73(2), pp. 349-360. 
[23] Glasow, P. (2005). Fundamintals of Survey Research Methodology. Washington C3 center: MITRE, pp. 1-20.

[24] Golafshani, N. (2003). Understanding reliability and validity in qualitative research, The Qualitative Report, vol. 8(4), pp. 597-607.

[25] Harmeyer, D. (2010). Reviving the reference interview: From desk to chat to phone, Reference Librarian, vol. 51(2), pp. 163-166.

[26] Herzog, R. and Bachman, J. (1981). Effects of Questionnaire Length on Response Quality, Public Opinion Quarterly, vol. 45(1), pp. 549559.

[27] Hoddinott, S. N. and Bass, M. J. (1986). The Diliman Total Design Survey Method: A Sure-Fire way to Get High Survey Return Rates, CAN. FAM. PHYSICIAN, vol. 32(11), pp. 2366-2368.

[28] Huang, X., Tian, G. L., Liu, Y. and Yu, J. W. (2015). Type IIcombination questionnaire model: A new survey design for a totally sensitive binary variable correlated with another nonsensitive binary variable, Journal of the Korean Statistical Society, vol. 44(3), pp. $432-447$.

[29] Ibn-Homaid, N. and Tijani, I. A. (2015). Financial Analysis of a Construction Company in Saudi Arabia, International Journal of Construction Engineering and Management, vol. 4(3), pp. 80-86.

[30] Jafarzadeh, R., Ingham, J., Walsh, K., Hassani, N. and Ghodrati Amiri, G. (2015). Using statistical regression analysis to establish construction cost models for seismic retrofit of confined masonry buildings, Journal of Construction Engineering and Management, vol. 141(5), pp. 1-11.

[31] James, P. (2014). Project Financial Management and Modern Financial Slavery: The Case of a KSA Metro Project Start-up, Asian Journal of Finance \& Accounting, vol. 6(2), p. 278-300.

[32] Khang, D. B. and Myint, Y. M. (1999). Time, cost and quality trade-off in project management: a case study, International Journal of Project Management, vol. 17(4), pp. 249-256.

[33] Konior, J. and Szóstak, M. (2020). Methodology of planning the course of the cumulative cost curve in construction projects, Sustainability, vol. 12(6), 1-22.

[34] Kraemer, H. C., Mintz, J., Noda, A., Tinklenberg, J. and Yesavage, J. A. (2006). Caution regarding the use of pilot studies to guide power calculations for study proposals, Archives of General Psychiatry, vol. 63(5), pp. 484-489.

[35] Krzywinski, M. and Altman, N. (2013). Power and sample size, Nature Methods, vol. 10(12), pp. 1139-1142.

[36] Makienko, I. and Bernard, E. K. (2012). Teaching applied value of marketing research: A questionnaire design project, International Journal of Management Education, vol. 10(2), pp. 139-145.

[37] Mason, M. (2010). FORUM: QUALITATIVE SOCIAL RESEARCH SOZIALFORSCHUNG Sample Size and Saturation in PhD Studies Using Qualitative Interviews, FORUM: QUALITATIVE SOCIAL RESEARCH SOZIALFORSCHUNG, vol. 11(3), pp. 1-19.

[38] Mieg, H. A. (2009). Two factors of expertise? Excellence and professionalism of environmental experts, High Ability Studies, vol. 20(1), pp. 91-115.

[39] Mohd Yasin Ă, R., Amin Nur Yunus, F., Che Rus, R., Ahmad, A. and Bekri Rahim, M. (2015). Validity and Reliability Learning Transfer Item Using Rasch Measurement Model, Procedia - Social and Behavioral Sciences, vol. 204(November), pp. $212-217$.

[40] Nazif, A., Mohammed, N. I., Malakahmad, A. and Abualqumboz, M. S. (2016). Application of Step Wise Regression Analysis in Predicting Future Particulate Matter Concentration Episode, Water, Air, and Soil Pollution, vol. 227(4), pp. 1-12.

[41] Naithani, P. and Jha, A. N. (2009) 'Challenges Faced by Expatriate Workers in Gulf Cooperation Council Countries', International Journal of Business and Management, vol. 5(1), pp. 98-103. doi: 10.5539/ijbm.v5n1p98.

[42] Pérez, M. and Pericchi, L. R. (2014). Changing statistical significance with the amount of information: The adaptive $\alpha$ significance level, Statistics and Probability Letters, vol. 85(1), pp. 20-24.

[43] Petroutsatou, K. and Lambropoulos, S. (2010). Road tunnels construction cost estimation: A structural equation model development and comparison, Operational Research, vol. 10(2), pp. 163-173.

[44] Radhi, H. (2009). Evaluating the potential impact of global warming on the UAE residential buildings - A contribution to reduce the CO2 emissions, Building and Environment, vol. 44(12), pp. 2451-2462.

[45] Ratner, B. (2009). The correlation coefficient: Its values range between 1/1, or do they?, Journal of Targeting, Measurement and Analysis for Marketing, vol. 17(2), pp. 139-142.

[46] Reja, U., Manfreda, K. L. and Hlebec, V. (2003). Open-ended vs . Close-ended Questions in Web Questionnaires, Developments in Applied Statistics, vol. 19(1), pp. 159-177. 
[47] Rodrigues, A. and Bowers, J. (1996). The role of system dynamics in project management, International Journal of Project Management, vol. 14(4), pp. 213-220.

[48] Ruiz, M. A., Gonza-ez-Porras, J. R., Aranguren, J. L., Franco, E., Villasante, F., Tunon, J., Gonza-lez-Lopez, T. J., Salas-Cansado, M. de and Soto, J. (2017). Development and validation of a new questionnaire measuring treatment satisfaction in patients with non-valvular atrial fibrillation: SAFUCA, Quality Life Research, vol. 4(1474), pp. 767-778.

[49] Rungtusanatham, M. J., Choi, T. Y., Hollingworth, D. G., Wu, Z. and Forza, C. (2003). Survey research in operations management: Historical analyses, Journal of Operations Management, vol. 21(4), pp. 475-488.

[50] Sauro, J. and Lewis, J. R. (2012). Chapter 8 - Standardized Usability Questionnaires. Second Edi, Quantifying the User Experience. Second Ed. Elsevier Inc.

[51] Saheem, W. (2016) 'The notion of expatriation in the United Arab Emirates', International Journal of Cross Cultural Management, vol. 16(3), pp. 301-320. doi: 10.1177/1470595816669532.

[52] Schober, P., Boer, C. M. and Schwarte, L. A. (2018). Correlation coefficients: Appropriate use and interpretation, Anesthesia and Analgesia, vol. 126(5), pp. 1763-1768.

[53] Shash, A. A. (1993). Factors considered in tendering in UK, Construction Management and Economics, vol. 11(1), pp. 111-118.

[54] Takim, R. and Akintoye, A. (2002). Performance Indicators for Successful Construction Project Performance, Association of Researchers in Construction Management, vol. 2(September), pp. 2-4.

[55] Tam, V. W. Y., Senaratne, S., Le, K. N., Shen, L.-Y., Perica, J. and Illankoon, I. M. C. S. (2017). Life-cycle cost analysis of green-building implementation using timber applications, Journal of Cleaner Production, vol. 147(1), pp. 458-469.

[56] Testa, M. A. and Simonson, D. C. (2009). The Use of Questionnaires and Surveys, Clinical and Translational Science. Boston. Ch.12.

[57] Toor, S.-R. and Ogunlana, S. O. (2009). Construction professionals' perception of critical success factors for large-scale construction projects, Construction Innovation: Information, Process, Management, vol. 9(2), pp. 149-167.

[58] Trafimow, D., Amrhein, V., Areshenkoff, C. N., Barrera-causil, C. J., Beh, E. J., Bilgiç, Y. K., Bono, R., Bradley, M. T., Briggs, W. M., Cepeda-freyre, H. A., Chaigneau, S. E., Ciocca, D. R., Correa, J. C., Cousineau, D., Boer, M. R. De, Dhar, S. S., Dolgov, I., Gómezbenito, J., Grendar, M., Grice, J. W., Guerrero-gimenez, M. E., Gutiérrez, A., Huedo-medina, T. B., Kosugi, K., Lachmair, M., Ledesma, R. D., Limongi, R., Badenes-ribera, L., Faulkenberry, T. J., Trafimow, D., Amrhein, V. and Marmolejo-ramos, F. (2018). Manipulating the Alpha Level Cannot Cure Significance Testing, Frontiers in Psychology, vol. 9(May), pp. 1-7.

[59] Trangkanont, S. and Charoenngam, C. (2014). Private partner's risk response in PPP low-cost housing projects, Property Management, vol. 32(1), pp. 67-94.

[60] Trier-Bieniek, a. (2012). Framing the telephone interview as a participant-centred tool for qualitative research: a methodological discussion, Qualitative Research, vol. 12(6), pp. 630-644.

[61] Vanderwal, T., Eilbott, J., Kelly, C., Frew, S. R., Woodward, T. S., Milham, M. P. and Castellanos, F. X. (2021). Stability and similarity of the pediatric connectome as developmental measures, NeuroImage, vol. 226(November), pp. 1-12.

[62] Vidogah, W. and Ndekugri, I. (1998). Improving the management of claims on construction contracts: Consultant's perspective, Construction Management and Economics, vol. 16(3), pp. 363-372.

[63] Winter, M., Smith, C., Morris, P. and Cicmil, S. (2006). Directions for future research in project management: The main findings of a UK government-funded research network, International Journal of Project Management, vol. 24(8), pp. 638-649.

[64] Yana, A. A. G. A., Rusdhi, H. A. and Wibowo, M. A. (2015). Analysis of factors affecting design changes in construction project with Partial Least Square (PLS), Procedia Engineering, vol. 125(1), pp. 40-45.

[65] Zimmermann, J. and Eber, W. (2017). Criteria on the Value of Expert's Opinions for Analyzing Complex Structures in Construction and Real Estate Management, Procedia Engineering, vol. 196(June), pp. 335-342. 
Journal of Entrepreneurship and Project Management

ISSN 2520-9116 (Online)

Vol. 6, Issue No.1, pp 90 -114, 2021

www.carijournals.org

\section{Appendix}

Correlation Analysis

\begin{tabular}{|c|c|c|c|c|c|c|c|c|c|}
\hline \multirow[b]{2}{*}{ SN } & \multirow[b]{2}{*}{ Cost Risk Description } & \multirow[b]{2}{*}{ Mean } & \multirow{2}{*}{$\begin{array}{l}\text { Standar d } \\
\text { Deviation }\end{array}$} & \multicolumn{3}{|c|}{$\begin{array}{c}\text { Correlation: } \\
\text { Risk vs Probability }\end{array}$} & \multicolumn{3}{|c|}{$\begin{array}{l}\text { Correlation: } \\
\text { Risk vs Impact }\end{array}$} \\
\hline & & & & $\begin{array}{c}\mathbf{r}- \\
\text { value }\end{array}$ & $\begin{array}{c}\mathbf{P} \text { - } \\
\text { value }\end{array}$ & $\begin{array}{c}\text { Linear } \\
\text { Relationship } \\
\text { Strength }\end{array}$ & $\begin{array}{c}\mathbf{r}- \\
\text { value }\end{array}$ & $\begin{array}{c}\mathbf{P}- \\
\text { value }\end{array}$ & $\begin{array}{c}\text { Linear } \\
\text { Relationship } \\
\text { Strength } \\
\end{array}$ \\
\hline $\mathbf{A}$ & Construction Activities' Risks & & & & & & & & \\
\hline $\mathbf{1}$ & Selection Method & 31.93 & 22.386 & 0.760 & 0.000 & Strong & 0.919 & 0.000 & Strong \\
\hline 2 & Type of Client: Solo Individual & 24.55 & 23.277 & 0.806 & 0.000 & Strong & 0.927 & 0.000 & Strong \\
\hline 3 & $\begin{array}{l}\text { Type of Client: Bank- Individual } \\
\text { Partnership }\end{array}$ & 22.58 & 17.649 & 0.493 & 0.000 & Weak & 0.780 & 0.000 & Strong \\
\hline 4 & Type of Client: Developer & 21.22 & 15.645 & 0.451 & 0.000 & Weak & 0.841 & 0.001 & Strong \\
\hline 5 & Type of Client: Group of People & 26.08 & 15.807 & 0.400 & 0.000 & Weak & 0.789 & 0.004 & Strong \\
\hline 6 & Location: City Area & 22.67 & 19.730 & 0.648 & 0.000 & Moderate & 0.943 & 0.000 & Strong \\
\hline 7 & Location: Regional Area & 22.84 & 18.129 & 0.312 & 0.020 & Weak & 0.914 & 0.000 & Strong \\
\hline 8 & Location: Beach Area & 23.55 & 16.722 & 0.737 & 0.000 & Strong & 0.841 & 0.000 & Strong \\
\hline 9 & Location: Desert Area & 31.65 & 23.420 & 0.801 & 0.000 & Strong & 0.919 & 0.000 & Strong \\
\hline 10 & $\begin{array}{l}\text { Buil ding Services Complexity: } \\
\text { Operational Services }\end{array}$ & 26.82 & 17.132 & 0.467 & 0.000 & Weak & 0.723 & 0.000 & Strong \\
\hline 11 & $\begin{array}{l}\text { Buil ding Services Complexity: Fitness } \\
\text { Services }\end{array}$ & 24.15 & 15.401 & 0.343 & 0.000 & Weak & 0.936 & 0.000 & Strong \\
\hline 12 & Number of Basement Levels & 22.56 & 18.953 & 0.709 & 0.000 & Strong & 0.828 & 0.000 & Strong \\
\hline 13 & Procurement Method & 29.20 & 17.190 & 0.426 & 0.000 & Weak & 0.846 & 0.000 & Strong \\
\hline 14 & Site Topography & 26.93 & 17.920 & 0.522 & 0.000 & Moderate & 0.856 & 0.000 & Strong \\
\hline 15 & Site Conditions & 29.33 & 20.110 & 0.620 & 0.000 & Moderate & 0.908 & 0.000 & Strong \\
\hline 16 & Working Space & 19.13 & 16.546 & 0.550 & 0.000 & Moderate & 0.880 & 0.000 & Strong \\
\hline 17 & Site Access & 19.91 & 18.686 & 0.660 & 0.000 & Moderate & 0.925 & 0.000 & Strong \\
\hline 18 & Frame Structure & 18.45 & 13.281 & 0.003 & 0.983 & $\begin{array}{c}\text { No } \\
\text { relationship }\end{array}$ & 0.884 & 0.000 & Strong \\
\hline 19 & Foundation Type & 18.87 & 13.951 & 0.092 & 0.514 & $\begin{array}{c}\text { No } \\
\text { relationship }\end{array}$ & 0.941 & 0.000 & Strong \\
\hline 20 & Ground Conditions & 30.31 & 17.055 & 0.247 & 0.069 & $\begin{array}{c}\text { No } \\
\text { relationship }\end{array}$ & 0.932 & 0.000 & Strong \\
\hline 21 & Type of Soil & 28.27 & 18.006 & 0.434 & 0.001 & Weak & 0.830 & 0.000 & Strong \\
\hline 22 & Mark-up Size & 17.85 & 16.672 & 0.630 & 0.000 & Moderate & 0.927 & 0.000 & Strong \\
\hline 23 & Need for Work & 17.67 & 14.934 & 0.383 & 0.004 & Weak & 0.881 & 0.000 & Strong \\
\hline 24 & Deadline Requirements & 36.71 & 20.623 & 0.659 & 0.000 & Moderate & 0.703 & 0.000 & Strong \\
\hline 25 & Number of Stories & 22.02 & 15.841 & 0.601 & 0.000 & Moderate & 0.893 & 0.000 & Strong \\
\hline 26 & Project Duration & 33.35 & 21.961 & 0.749 & 0.000 & Strong & 0.849 & 0.000 & Strong \\
\hline
\end{tabular}


Journal of Entrepreneurship and Project Management

ISSN 2520-9116 (Online)

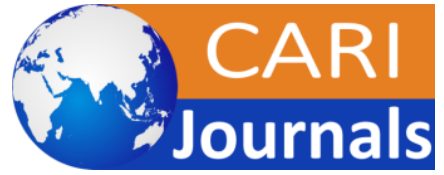

Vol. 6, Issue No.1, pp 90 -114, 2021

www.carijournals.org

\begin{tabular}{|c|c|c|c|c|c|c|c|c|c|}
\hline \multirow{2}{*}{ SN } & \multirow{2}{*}{ Cost Risk Description } & \multirow{2}{*}{ Mean } & \multirow{2}{*}{$\begin{array}{l}\text { Standard } \\
\text { Deviation }\end{array}$} & \multicolumn{2}{|c|}{$\begin{array}{c}\text { Correlation: } \\
\text { Risk vs } \\
\text { Probability } \\
\end{array}$} & \multirow[b]{2}{*}{$\begin{array}{c}\text { Linear } \\
\text { Relationship } \\
\text { Strength } \\
\end{array}$} & \multicolumn{2}{|c|}{$\begin{array}{c}\text { Correlation: } \\
\text { Risk vs Impact } \\
\end{array}$} & \multirow[b]{2}{*}{$\begin{array}{c}\text { Linear } \\
\text { Relationship } \\
\text { Strength } \\
\end{array}$} \\
\hline & & & & $\begin{array}{c}\mathbf{r}- \\
\text { value }\end{array}$ & $\begin{array}{c}\mathbf{P} \text { - } \\
\text { value }\end{array}$ & & $\begin{array}{c}\mathbf{r}- \\
\text { value }\end{array}$ & $\begin{array}{c}P \text { - } \\
\text { value }\end{array}$ & \\
\hline 27 & Gross Floor Area & 21.45 & 16.726 & 0.566 & 0.000 & Moderate & 0.769 & 0.000 & Strong \\
\hline 28 & Equipment Required & 25.80 & 18.664 & 0.378 & 0.004 & Weak & 0.941 & 0.000 & Strong \\
\hline 29 & Construction Technology Availability & 30.67 & 21.461 & 0.652 & 0.000 & Moderate & 0.891 & 0.000 & Strong \\
\hline B & \multicolumn{9}{|l|}{ Political Risks } \\
\hline $\mathbf{1}$ & Change in Law & 27.44 & 23599 & 0.744 & 0.000 & Strong & 0.802 & 0.000 & Strong \\
\hline 2 & Delay in Project Approvals and Permits & 41.41 & 20.110 & 0.598 & 0.000 & Moderate & 0.846 & 0.000 & Strong \\
\hline 3 & Poor Public Decision-Making Process & 31.54 & 17959 & 0.547 & 0.000 & Moderate & 0.837 & 0.000 & Strong \\
\hline 4 & Government Intervention & 30.57 & 19.296 & 0.633 & 0.000 & Moderate & 0.866 & 0.000 & Strong \\
\hline 5 & Unstable Government & 36.65 & 25307 & 0.850 & 0.000 & Strong & 0.713 & 0.000 & Strong \\
\hline 6 & Government Reliability & 38.26 & 23.664 & 0.698 & 0.000 & Moderate & 0.848 & 0.000 & Strong \\
\hline 7 & Inconsistencies in Government Policies & 29.35 & 22.868 & 0.834 & 0.000 & Strong & 0.806 & 0.000 & Strong \\
\hline 8 & Strong Political Opposition / Hostility & 27.07 & 23.768 & 0.812 & 0.000 & Strong & 0.736 & 0.000 & Strong \\
\hline 9 & Expropriation/ Nationalization of Assets & 26.44 & 22576 & 0.775 & 0.000 & Strong & 0.687 & 0.000 & Moderate \\
\hline 10 & Inability of Concessionaire & 22.56 & 19908 & 0.160 & 0.247 & $\begin{array}{c}\text { No } \\
\text { relationship }\end{array}$ & 0.752 & 0.000 & Strong \\
\hline $\mathbf{C}$ & \multicolumn{9}{|l|}{ Legal Risks } \\
\hline $\mathbf{1}$ & Change in Tax Regulation & 30.47 & 22963 & 0.915 & 0.000 & Strong & 0.920 & 0.000 & Strong \\
\hline 2 & Corruption and Lack of Respect for Law & 30.96 & 22.622 & 0.796 & 0.000 & Strong & 0.746 & 0.000 & Strong \\
\hline 3 & Legislation Change & 25.56 & 19.411 & 0.727 & 0.000 & Strong & 0.888 & 0.000 & Strong \\
\hline 4 & Import/ Export Restrictions & 22.83 & 19.872 & 0.731 & 0.000 & Strong & 0.865 & 0.000 & Strong \\
\hline 5 & Rate of Return Restrictions & 18.61 & 19.755 & 0.779 & 0.000 & Strong & 0.898 & 0.000 & Strong \\
\hline 6 & Industrial Regulatory Change & 24.98 & 20551 & 0.818 & 0.000 & Strong & 0.889 & 0.000 & Strong \\
\hline $\mathbf{D}$ & \multicolumn{9}{|l|}{ Economic Change Risks } \\
\hline $\mathbf{1}$ & Interest Rate Volatility & 22.67 & 20536 & 0.750 & 0.000 & Strong & 0.948 & 0.000 & Strong \\
\hline 2 & Inflation Rate Volatility & 26.22 & 21914 & 0.481 & 0.000 & Weak & 0.960 & 0.000 & Strong \\
\hline 3 & Foreign Ex change and Convert & 20.63 & 17.709 & 0.707 & 0.000 & Strong & 0.807 & 0.000 & Strong \\
\hline 4 & Poor Financial Market & 30.45 & 19.669 & 0.751 & 0.000 & Strong & 0.832 & 0.000 & Strong \\
\hline
\end{tabular}


Journal of Entrepreneurship and Project Management

ISSN 2520-9116 (Online)

Vol. 6, Issue No.1, pp 90 -114, 2021

www.carijournals.org

\begin{tabular}{|c|c|c|c|c|c|c|c|c|c|}
\hline \multirow{2}{*}{ SN } & \multirow{2}{*}{ Cost Risk Description } & \multirow{2}{*}{ Mean } & \multirow{2}{*}{$\begin{array}{l}\text { Standard } \\
\text { Deviation }\end{array}$} & \multicolumn{3}{|c|}{$\begin{array}{c}\text { Correlation: } \\
\text { Risk vs Probability }\end{array}$} & \multicolumn{3}{|c|}{$\begin{array}{c}\text { Correlation: } \\
\text { Risk vs Impact }\end{array}$} \\
\hline & & & & $\begin{array}{c}\mathbf{r}- \\
\text { value }\end{array}$ & $\begin{array}{c}P \text { - } \\
\text { value }\end{array}$ & $\begin{array}{c}\text { Linear } \\
\text { Relation ship } \\
\text { Strength } \\
\end{array}$ & $\begin{array}{c}\mathbf{r}- \\
\text { value }\end{array}$ & $\begin{array}{c}P \text { - } \\
\text { value }\end{array}$ & $\begin{array}{c}\text { Linear } \\
\text { Relationship } \\
\text { Strength } \\
\end{array}$ \\
\hline $\mathbf{E}$ & Natural Risks & & & & & & & & \\
\hline 1 & Force Majeure & 1835 & 18.789 & 0.660 & 0.000 & Moderate & 0.673 & 0.000 & Moderate \\
\hline 2 & Environment & 18.07 & 17.122 & 0.615 & 0.000 & Moderate & 0.874 & 0.000 & Strong \\
\hline 3 & Weather & 17.44 & 16.317 & 0.513 & 0.000 & Moderate & 0.919 & 0.000 & Strong \\
\hline 4 & Geotechnical Condition & 23.69 & 18.247 & 0.085 & 0.541 & $\begin{array}{c}\text { No } \\
\text { relationship }\end{array}$ & 0.923 & 0.000 & Strong \\
\hline $\mathbf{F}$ & Market Risks & & & & & & & & \\
\hline 1 & Market Supply & 25.11 & 20.860 & 0.737 & 0.000 & Strong & 0.872 & 0.000 & Strong \\
\hline 2 & Market Dem and & 27.07 & 23.514 & 0.787 & 0.000 & Strong & 0.958 & 0.000 & Strong \\
\hline 3 & Fluctuation of Material Cost by Public/Private & 24.81 & 20.746 & 0.721 & 0.000 & Strong & 0.889 & 0.000 & Strong \\
\hline 4 & Value of Production Effort & 22.30 & 20.355 & 0.675 & 0.000 & Moderate & 0.886 & 0.000 & Strong \\
\hline G & Project Selection Risks & & & & & & & & \\
\hline 1 & Public Opposition to Projects & 1854 & 20.705 & 0.779 & 0.000 & Strong & 0.779 & 0.000 & Strong \\
\hline 2 & Uncompetitive Tender & 2550 & 20.831 & 0.689 & 0.000 & Moderate & 0.946 & 0.000 & Strong \\
\hline 3 & Level of Demand for the Project & 24.19 & 19.179 & 0.726 & 0.000 & Strong & 0.761 & 0.000 & Strong \\
\hline 4 & Land Acquisition & 25.00 & 18.473 & 0.706 & 0.000 & Strong & 0.826 & 0.000 & Strong \\
\hline 5 & Competition Risk & 19.61 & 18.296 & 0.654 & 0.000 & Moderate & 0.930 & 0.000 & Strong \\
\hline $\mathbf{H}$ & Project Finance Risks & & & & & & & & \\
\hline 1 & Inaccurate Estim ates & 31.41 & 22.055 & 0.778 & 0.000 & Strong & 0.804 & 0.000 & Strong \\
\hline 2 & High Finance Cost & 26.26 & 21.016 & 0.713 & 0.000 & Strong & 0.830 & 0.000 & Strong \\
\hline 3 & High Bidding Costs & 26.85 & 20.754 & 0.733 & 0.000 & Strong & 0.814 & 0.000 & Strong \\
\hline 4 & Delay in Payment of Annuity & 2798 & 20.087 & 0.732 & 0.000 & Strong & 0.856 & 0.000 & Strong \\
\hline 5 & Financial Attraction of Project to Investors & 23.89 & 17.372 & 0.647 & 0.000 & Moderate & 0.863 & 0.000 & Strong \\
\hline 6 & Lack of Creditworthiness & 22.87 & 17.394 & 0.661 & 0.000 & Moderate & 0.855 & 0.000 & Strong \\
\hline 7 & Delay in Financial Closure & 27.85 & 19.082 & 0.558 & 0.000 & Moderate & 0.745 & 0.000 & Strong \\
\hline 8 & Inability to Service Debt & 26.41 & 17.615 & 0.509 & 0.000 & Moderate & 0.704 & 0.000 & Strong \\
\hline 9 & Lack of Government Guarantees & 23.47 & 20.526 & 0.697 & 0.000 & Moderate & 0.911 & 0.000 & Strong \\
\hline 10 & Financer Unwilling to Take High Risk & 28.09 & 20.574 & 0.559 & 0.000 & Moderate & 0.836 & 0.000 & Strong \\
\hline
\end{tabular}


Journal of Entrepreneurship and Project Management

ISSN 2520-9116 (Online)

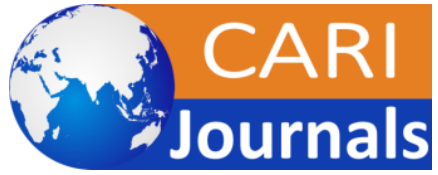

Vol. 6, Issue No.1, pp 90 -114, 2021

www.carijournals.org

\begin{tabular}{|c|c|c|c|c|c|c|c|c|c|}
\hline \multirow{2}{*}{ SN } & \multirow{2}{*}{ Cost Risk Description } & \multirow{2}{*}{ Mean } & \multirow{2}{*}{$\begin{array}{l}\text { Standard } \\
\text { Deviation }\end{array}$} & \multicolumn{3}{|c|}{$\begin{array}{c}\text { Correlation: } \\
\text { Risk vs Probability }\end{array}$} & \multicolumn{3}{|c|}{$\begin{array}{c}\text { Correlation: } \\
\text { Risk vs Impact }\end{array}$} \\
\hline & & & & $\begin{array}{c}\mathbf{r}- \\
\text { value }\end{array}$ & $\begin{array}{c}P \text { - } \\
\text { value }\end{array}$ & $\begin{array}{c}\text { Linear } \\
\text { Relationship } \\
\text { Strength } \\
\end{array}$ & $\begin{array}{c}\mathbf{r}- \\
\text { value }\end{array}$ & $\begin{array}{c}P \text { - } \\
\text { value }\end{array}$ & $\begin{array}{c}\text { Linear } \\
\text { Relationship } \\
\text { Strength }\end{array}$ \\
\hline I & Building Functionality and Serviceability Risks & & & & & & & & \\
\hline 1 & Construction Time Delay & 33.24 & 23.063 & 0.563 & 0.000 & Moderate & 0.927 & 0.000 & Strong \\
\hline 2 & Material Avail ability & 21.72 & 19.022 & 0.650 & 0.000 & Moderate & 0.962 & 0.000 & Strong \\
\hline 3 & Labour Availability & 24.48 & 21.043 & 0.701 & 0.000 & Strong & 0.908 & 0.000 & Strong \\
\hline 4 & Poor Quality of Workmanship & 27.72 & 22.443 & 0.805 & 0.000 & Strong & 0.935 & 0.000 & Strong \\
\hline 5 & Default of Sub-Contractors or Suppliers & 27.26 & 22.192 & 0.690 & 0.000 & Moderate & 0.923 & 0.000 & Strong \\
\hline 6 & Design \& Construction Complexity & 28.86 & 20.276 & 0.702 & 0.000 & Strong & 0912 & 0.000 & Strong \\
\hline 7 & Design Deficiency & 3437 & 21.935 & 0.831 & 0.000 & Strong & 0.803 & 0.000 & Strong \\
\hline 8 & Late Design Change & 33.24 & 20.054 & 0.760 & 0.000 & Strong & 0907 & 0.000 & Strong \\
\hline 9 & Construction Technology Complexity & 24.09 & 17.485 & 0.434 & 0.001 & Weak & 0.877 & 0.000 & Strong \\
\hline 10 & Contractual Risk & 24.61 & 16.973 & 0.588 & 0.000 & Moderate & 0.899 & 0.000 & Strong \\
\hline 11 & Contractor Failure & 36.29 & 20.888 & 0.535 & 0.000 & Moderate & 0.748 & 0.000 & Strong \\
\hline 12 & Quality and Reliability & 25.17 & 18.248 & 0.642 & 0.000 & Moderate & 0.867 & 0.000 & Strong \\
\hline $\mathbf{J}$ & Stakeholders Relationship Risks & & & & & & & & \\
\hline 1 & Different Working Method Between Partners & 22.67 & 16.968 & 0.582 & 0.000 & Moderate & 0916 & 0.000 & Strong \\
\hline 2 & Inadequate Experience in Residential Projects & 25.85 & 18.700 & 0.501 & 0.000 & Moderate & 0.790 & 0.000 & Strong \\
\hline 3 & Lack of Commitment From Public/Private Sector & 24.80 & 16.725 & 0.569 & 0.000 & Moderate & 0.818 & 0.000 & Strong \\
\hline 4 & Organization and Coordination Risk & 1783 & 15.720 & 0.536 & 0.000 & Moderate & 0.778 & 0.000 & Strong \\
\hline 5 & Inadequate Distribution of Responsibility \& Risk & 20.61 & 17.066 & 0.622 & 0.000 & Moderate & 0.889 & 0.000 & Strong \\
\hline 6 & Inadequate Negotiation Period Prior to Initiation & 20.26 & 13.902 & 0.584 & 0.000 & Moderate & 0.769 & 0.000 & Strong \\
\hline 7 & Conflict Between Project's Participants & 23.19 & 17.059 & 0.675 & 0.000 & Moderate & 0.785 & 0.000 & Strong \\
\hline 8 & Workers Strike & 19.20 & 18.867 & 0.738 & 0.000 & Strong & 0.870 & 0.000 & Strong \\
\hline 9 & Cultural Differences Between Main Stakeholders & 15.06 & 14.330 & 0.689 & 0.000 & Moderate & 0.835 & 0.000 & Strong \\
\hline $\mathrm{K}$ & Knowledge Risks & & & & & & & & \\
\hline 1 & Expertise & 26.26 & 18.559 & 0.550 & 0.000 & Moderate & 0.827 & 0.000 & Strong \\
\hline 2 & Familiarities & 21.17 & 15.358 & 0.534 & 0.000 & Moderate & 0.871 & 0.000 & Strong \\
\hline 3 & Number of Bidders & 20.02 & 15.540 & 0.378 & 0.005 & Weak & 0.966 & 0.000 & Strong \\
\hline
\end{tabular}


Journal of Entrepreneurship and Project Management

ISSN 2520-9116 (Online)

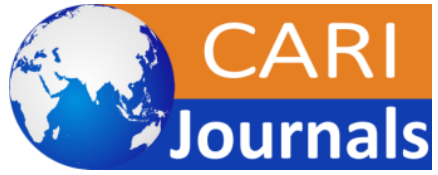

Vol. 6, Issue No.1, pp 90 -114, 2021

www.carijournals.org

\begin{tabular}{|c|c|c|c|c|c|c|c|c|c|}
\hline \multirow{2}{*}{ SN } & \multirow{2}{*}{ Cost Risk Description } & \multirow{2}{*}{ Mean } & \multirow{2}{*}{$\begin{array}{l}\text { Standard } \\
\text { Deviation }\end{array}$} & \multicolumn{3}{|c|}{$\begin{array}{c}\text { Correlation: } \\
\text { Risk vs Probability }\end{array}$} & \multicolumn{3}{|c|}{$\begin{array}{l}\text { Correlation: } \\
\text { Risk vs Imp act }\end{array}$} \\
\hline & & & & $\begin{array}{c}\mathrm{r}- \\
\text { value }\end{array}$ & $\begin{array}{c}\mathrm{P} \text { - } \\
\text { value }\end{array}$ & $\begin{array}{c}\text { Linear } \\
\text { Relationship } \\
\text { Strength }\end{array}$ & $\begin{array}{c}\mathrm{r}- \\
\text { value }\end{array}$ & $\begin{array}{c}\mathrm{P} \text { - } \\
\text { value }\end{array}$ & $\begin{array}{c}\text { Linear } \\
\text { Relationship } \\
\text { Strength } \\
\end{array}$ \\
\hline 4 & Market Conditions & 25.70 & 20.870 & 0.728 & 0.000 & Strong & 0.922 & 0.000 & Strong \\
\hline 5 & Size of the Project & 25.69 & 21.231 & 0.735 & 0.000 & Strong & 0.884 & 0.000 & Strong \\
\hline 6 & Type of Building & 23.19 & 19.125 & 0.656 & 0.000 & Moderate & 0931 & 0.000 & Strong \\
\hline 7 & Extent of Database & 17.11 & 15.633 & 0.633 & 0.000 & Moderate & 0.839 & 0.000 & Strong \\
\hline 8 & Homogeneity of Samples & 14.89 & 15.298 & 0.585 & 0.000 & Moderate & 0958 & 0.000 & Strong \\
\hline 9 & Details of Information & 21.74 & 19.511 & 0.662 & 0.000 & Moderate & 0932 & 0.000 & Strong \\
\hline 0 & OPEX Activities' Risks & & & & & & & & \\
\hline 1 & Energy Costs & 27.19 & 21.098 & 0.673 & 0.000 & Moderate & 0.829 & 0.000 & Strong \\
\hline 2 & Service Life of Building Components & 23.00 & 18.703 & 0.585 & 0.000 & Moderate & 0943 & 0.000 & Strong \\
\hline 3 & Building Components' Eco-Costs & 1731 & 15.076 & 0.605 & 0.000 & Moderate & 0.886 & 0.000 & Strong \\
\hline 4 & Asset Operation Eco-Costs & 1835 & 14.947 & 0.604 & 0.000 & Moderate & 0918 & 0.000 & Strong \\
\hline 5 & Disposal Eco-Costs & 16.09 & 15.966 & 0.653 & 0.000 & Moderate & 0950 & 0.000 & Strong \\
\hline 6 & Components' Deterioration Rate & 1754 & 17.103 & 0.747 & 0.000 & Strong & 0921 & 0.000 & Strong \\
\hline 7 & Fabric Maintenance & 16.02 & 13.216 & 0.402 & 0.003 & Weak & 0919 & 0.000 & Strong \\
\hline 8 & Services & 2193 & 15.286 & 0.461 & 0.000 & Weak & 0930 & 0.000 & Strong \\
\hline 9 & Equipment's Maintenance & 21.88 & 13.414 & 0.494 & 0.000 & Weak & 0935 & 0.000 & Strong \\
\hline 10 & Overheads & 2056 & 17.649 & 0.308 & 0.000 & Weak & 0918 & 0.000 & Strong \\
\hline 11 & Utilities & 22.81 & 14.523 & 0.209 & 0.129 & $\begin{array}{c}\text { No } \\
\text { relationship }\end{array}$ & 0933 & 0.000 & Strong \\
\hline 12 & Cleaning & 15.09 & 12.363 & 0.408 & 0.002 & Weak & 0.802 & 0.000 & Strong \\
\hline 13 & Percentage of Current Replacement Value & 17.76 & 14.762 & 0.396 & 0.000 & Weak & 0915 & 0.000 & Strong \\
\hline 14 & Ratio of Maintenance to Capital Cost & 19.19 & 15.857 & 0.547 & 0.000 & Moderate & 0908 & 0.000 & Strong \\
\hline 15 & Ratio of Operation to Capital Cost & 22.22 & 16.769 & 0.617 & 0.000 & Moderate & 0.894 & 0.000 & Strong \\
\hline
\end{tabular}




\section{Regression Modelling}

\begin{tabular}{|c|c|c|c|c|c|c|c|c|c|c|}
\hline \multirow{2}{*}{ SN } & \multirow{2}{*}{ Cost Risk Description } & \multicolumn{6}{|c|}{ Regression Analysis } & \multirow{2}{*}{$\begin{array}{c}\text { Valid } \\
\text { Sample } \\
\text { Size }\end{array}$} & \multirow{2}{*}{$\begin{array}{l}\text { Number of } \\
\text { Iterations }\end{array}$} & \multirow{2}{*}{$\begin{array}{l}\text { Number } \\
\text { of Outlier }\end{array}$} \\
\hline & & Sig. & $\begin{array}{c}\mathbf{R}- \\
\text { Square } \\
\end{array}$ & $\begin{array}{l}\text { Durbin- } \\
\text { Watson } \\
\end{array}$ & $\begin{array}{c}\text { Std. } \\
\text { Residual }\end{array}$ & Equation & $\begin{array}{l}\text { Equation } \\
\text { Reference }\end{array}$ & & & \\
\hline $\mathbf{A}$ & \multicolumn{10}{|l|}{ Construction Activities' Risks } \\
\hline 1 & Selection Method & 0.000 & 0.956 & 2.071 & 0.000 & $\mathrm{Y}_{\text {CAl1.1 }}=-27.785+0.461 \mathrm{X}_{\text {prob }}+0.649 \mathrm{X}_{\mathrm{inp}}$ & Eq.5- CA1 & 55 & 1 & 0 \\
\hline 2 & Type of Client: Solo Individual & 0.000 & 0.945 & 1.605 & 0.000 & $Y_{\text {CA2.1 }}=-20.684+0.362 X_{\text {proh }}+0.663 X_{\text {imp }}$ & Eq.5- CA2 & 55 & 1 & 0 \\
\hline 3 & $\begin{array}{l}\text { Type of Client: Bank- Individual } \\
\text { Partnership }\end{array}$ & 0.000 & 0.840 & 2.178 & 0.000 & $Y_{\text {CA3.1 }}=-19.336+0.399 X_{\text {proh }}+0.481 X_{\text {imp }}$ & Eq.5- CA3 & 55 & 1 & 0 \\
\hline 4 & Type of Client: Developer & 0.000 & 0.943 & 2.107 & 0.000 & $\mathrm{Y}_{\mathrm{CA} 4 . \mathrm{I}}=-24.268+0.418 \mathrm{X}_{\mathrm{proh}}+0.577 \mathrm{X}_{\mathrm{imp}}$ & Eq.5-CA4 & 55 & 1 & 0 \\
\hline 5 & Type of Client: Group of People & 0.000 & 0.955 & 1.536 & 0.000 & $Y_{\text {CA5.lc }}=-29.351+0.519 X_{\text {prob }}+0.558 X_{\text {imp }}$ & Eq.5- CA5 & 50 & 3 & 5 \\
\hline 6 & Location: City Area & 0.000 & 0.972 & 2.007 & 0.000 & $\mathrm{Y}_{\text {CA6.1 }}=-24.410+0.405 \mathrm{X}_{\mathrm{proh}}+0.650 \mathrm{X}_{\mathrm{imp}}$ & Eq.5-CA6 & 55 & 1 & 0 \\
\hline 7 & Location: Regional Area & 0.000 & 0.943 & 1.898 & 0.000 & $\mathrm{Y}_{\mathrm{CA} 7 \mathrm{l}}=-21.507+0.341 \mathrm{X}_{\mathrm{prob}}+0.628 \mathrm{X}_{\mathrm{imp}}$ & Eq.5- CA7 & 55 & 1 & 0 \\
\hline 8 & Location: Beach Area & 0.000 & 0.930 & 2.153 & 0.000 & $Y_{\text {CAB.1 }}=-19.832+0.431 X_{\text {prob }}+0.487 X_{\text {inp }}$ & Eq.5- CA8 & 55 & 1 & 0 \\
\hline 9 & Location: Desert Area & 0.000 & 0.967 & 1.603 & 0.000 & $Y_{\mathrm{CA9} .1 \mathrm{~d}}=-41.191+0.723 X_{\mathrm{prob}}+0.5549 X_{\mathrm{imp}}$ & Eq.5-CA9 & 52 & 3 & 3 \\
\hline 10 & $\begin{array}{l}\text { Building Services Complexity: } \\
\text { Operational Services }\end{array}$ & 0.000 & 0.898 & 2.212 & 0.000 & $\mathrm{Y}_{\mathrm{CA} 10.1}=-28.441+0.514 \mathrm{X}_{\mathrm{prob}}+0.529 \mathrm{X}_{\mathrm{imp}}$ & Eq.5-CA10 & 55 & 1 & 0 \\
\hline 11 & $\begin{array}{l}\text { Building Services Complexity: } \\
\text { Fitness Services }\end{array}$ & 0.000 & 0.958 & 1.903 & 0.000 & $\mathrm{Y}_{\mathrm{CA11.1}}=-10.250+0.234 \mathrm{X}_{\mathrm{prob}}+0.490 \mathrm{X}_{\mathrm{imp}}$ & Eq.5- CA11 & 55 & 1 & 0 \\
\hline 12 & Number of Basement Levels & 0.000 & 0.920 & 1.636 & 0.000 & $\mathrm{Y}_{\mathrm{CA12.1}}=22.151+0.197 \mathrm{X}_{\mathrm{pruu}}+0.181 \mathrm{X}_{\mathrm{Imp}}$ & Eq.5 CA12 & 55 & 1 & o \\
\hline 13 & Procurement Method & 0.000 & 0.947 & 2.005 & 0.000 & $Y_{\mathrm{CA} 13.1}=-32.193+0.502 X_{\text {prob }}+0.636 X_{\text {inp }}$ & Eq.5-CA13 & 55 & 1 & o \\
\hline 14 & Site Topography & 0.000 & 0.924 & 2.433 & 0.000 & $Y_{\mathrm{CA14.1}}=-24.830+0.397 \mathrm{X}_{\mathrm{prob}}+0.622 \mathrm{X}_{\mathrm{imp}}$ & Eq.5-CA14 & 55 & 1 & o \\
\hline 15 & Site Conditions & 0.000 & 0.946 & 2.032 & 0.000 & $Y_{C A 15.1}=-26.255+0.400 X_{\text {prob }}+0.668 X_{\text {imp }}$ & Eq.5-CA15 & 55 & 1 & 0 \\
\hline 16 & Working Space & 0.000 & 0.921 & 1.841 & 0.000 & $Y_{\mathrm{CA16.1}}=-17.034+0.339 \mathrm{X}_{\mathrm{prob}}+0.531 \mathrm{X}_{\mathrm{imp}}$ & Eq.5-CA16 & 55 & 1 & 0 \\
\hline 17 & Site Access & 0.000 & 0.945 & 1.979 & 0.000 & $Y_{\mathrm{CA17.1}}=-17.168+0.285 \mathrm{X}_{\mathrm{prob}}+0.656 \mathrm{X}_{\mathrm{imp}}$ & Eq.5-CA17 & 55 & 1 & 0 \\
\hline 18 & Frame Structure & 0.000 & 0.940 & 1.503 & 0.000 & $Y_{\mathrm{CA} 18 . \mathrm{lc}}=-18.767+0.272 \mathrm{X}_{\mathrm{prob}}+0.616 \mathrm{X}_{\mathrm{imp}}$ & Eq.5-CA18 & 51 & 3 & 4 \\
\hline 19 & Foundation Type & 0.000 & 0.952 & 1.913 & 0.000 & $Y_{\text {CA19.1b }}=-15.876+0.597 X_{\text {prob }}+0.257 X_{\text {imp }}$ & Eq.5-CA19 & 53 & 2 & 2 \\
\hline
\end{tabular}

\begin{tabular}{|c|c|c|c|c|c|c|c|c|c|c|}
\hline \multirow{2}{*}{ SN } & \multirow{2}{*}{ Cost Risk Description } & \multicolumn{6}{|c|}{ Regression Analysis } & \multirow{2}{*}{$\begin{array}{c}\text { Valid } \\
\text { Sample } \\
\text { Size }\end{array}$} & \multirow{2}{*}{$\begin{array}{l}\text { Number of } \\
\text { Iterations }\end{array}$} & \multirow{2}{*}{$\begin{array}{l}\text { Number } \\
\text { of Outlier }\end{array}$} \\
\hline & & Sig. & $\begin{array}{l}\mathrm{R}- \\
\text { Square }\end{array}$ & $\begin{array}{l}\text { Durbin- } \\
\text { Watson }\end{array}$ & $\begin{array}{l}\text { Std. } \\
\text { Residual }\end{array}$ & Equation & $\begin{array}{c}\text { Equation } \\
\text { Reference }\end{array}$ & & & \\
\hline 20 & Ground Conditions & 0.000 & 0.951 & 1.708 & 0.000 & $Y_{C A X]}=-19.644+0.295 X_{p r d}+0.674 X_{\text {ing }}$ & Eq.5-CA20 & 55 & 1 & 0 \\
\hline 21 & Type of Soil & 0.000 & 0.920 & 1.693 & 0.000 & $Y_{\text {CA21.1 }}=-30.697+0.495 X_{\mathrm{rmb}}+0.607 \mathrm{X}_{\mathrm{imp}}$ & Eq.5-CA21 & 55 & 1 & $\mathbf{0}$ \\
\hline 22 & Mark-up Size & 0.000 & 0.951 & 1.737 & 0.000 & $\mathrm{Y}_{\mathrm{CA} 21}=-15.493+0.309 \mathrm{X}_{\mathrm{pmb}}+0.556 \mathrm{X}_{\mathrm{imp}}$ & Eq.5- CA22 & 55 & 1 & 0 \\
\hline 23 & Need for Work & 0.000 & 0.937 & 1.996 & 0.000 & $Y_{C A 2 A 1}=-18.179+0.322 X_{p a b}+0.560 X_{i m p}$ & Eq.5- CA23 & 55 & 1 & 0 \\
\hline 24 & Deadline Requirements & 0.000 & 0.925 & 1.768 & 0.000 & $\mathrm{Y}_{\mathrm{CA24.1}}=-36.991+0.646 \mathrm{X}_{\mathrm{pms}}+0.572 \mathrm{X}_{\mathrm{imp}}$ & Eq.5-CA24 & 55 & 1 & 0 \\
\hline 25 & Number of Stories & 0.000 & 0.948 & 2.124 & 0.000 & $Y_{C A S A}=-19.151+0.402 X_{\mathrm{pmb}}+0.502 X_{\mathrm{impp}}$ & Eq.5-CA25 & 55 & 1 & 0 \\
\hline 26 & Project Duration & 0.000 & 0.972 & 2.127 & 0.000 & 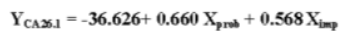 & Eq.5-CA26 & 55 & 1 & 0 \\
\hline 27 & Gross Floor Area & 0.000 & 0.882 & 1.867 & 0.000 & $\mathrm{Y}_{\mathrm{CAZ \Lambda}}=-21.393+0.433 \mathrm{X}_{\mathrm{pma}}+0.494 \mathrm{X}_{\mathrm{imp}}$ & Eq.5- $\mathrm{CA}_{27}$ & 55 & 1 & 0 \\
\hline 28 & Equipment Required & 0.000 & 0.955 & 2.148 & 0.000 & $\mathrm{Y}_{\mathrm{CASS}}=-17.916+0.315 \mathrm{X}_{\mathrm{prab}}+0.596 \mathrm{X}_{\mathrm{imp}}$ & Eq.5-CA28 & 55 & 1 & 0 \\
\hline 29 & $\begin{array}{l}\text { Construction Technology } \\
\text { Availability }\end{array}$ & 0.000 & 0.950 & 1.699 & 0.000 & $Y_{C A Y 1}=-30.265+0.509 X_{p m b}+0.621 X_{\text {imp }}$ & Eq.5-CA29 & 55 & 1 & 0 \\
\hline B & \multicolumn{10}{|l|}{ Political Risks } \\
\hline 1 & Change in Law & 0.000 & 0.921 & 1.782 & 0.000 & $\mathrm{Y}_{\mathrm{CB} 1.1}=-26.362+0.546 \mathrm{X}_{\mathrm{prab}}+0.517 \mathrm{X}_{\mathrm{m} q \mathrm{q}}$ & Eq.5- CB1 & 54 & 1 & 0 \\
\hline 2 & $\begin{array}{l}\text { Delay in Project Approvals and } \\
\text { Permits }\end{array}$ & 0.000 & 0.962 & 1.796 & 0.000 & $\mathrm{Y}_{\mathrm{CB} 2.1}=-39.873+0.622 \mathrm{X}_{\mathrm{prbb}}+0.644 \mathrm{X}_{\mathrm{m} \mathrm{p}}$ & Eq.5- CB2 & 54 & 1 & 0 \\
\hline 3 & $\begin{array}{l}\text { Poor Public Decision Making } \\
\text { Process }\end{array}$ & 0.000 & 0.946 & 1.965 & 0.000 & $Y_{\mathrm{CB} 3.1}=-28.624+0.528 \mathrm{X}_{\mathrm{prab}}+0.549 \mathrm{X}_{\mathrm{mp}}$ & Eq.5- CB3 & 54 & 1 & $\mathbf{0}$ \\
\hline 4 & Government Intervention & 0.000 & 0.942 & 2.008 & 0.000 & $\mathrm{Y}_{\mathrm{CB} A .1}=-24.614+0.451 \mathrm{X}_{\mathrm{prbb}}+0.575 \mathrm{X}_{\mathrm{m}}$ & Eq.5- CB4 & 54 & 1 & $\mathbf{0}$ \\
\hline 5 & Unstable Government & 0.000 & 0.955 & 1.789 & 0.000 & $\mathrm{Y}_{\mathrm{CBS} .1}=-31.328+0.699 \mathrm{X}_{\mathrm{prob}}+0.466 \mathrm{X}_{\mathrm{m}}$ & Eq.5- CB5 & 54 & 1 & $\mathbf{0}$ \\
\hline 6 & Government Reliability & 0.000 & 0.932 & 2.145 & 0.000 & $Y_{C B G .1}=-29.046+0.524 X_{p r b b}+0.592 X_{i m p}$ & Eq.5- CB6 & 54 & 1 & $\mathbf{0}$ \\
\hline 7 & $\begin{array}{l}\text { Inconsistencies in Govemment } \\
\text { Policies }\end{array}$ & 0.000 & 0.938 & 1.775 & 0.000 & $Y_{\mathrm{CB} .1}=-28.005+0.622 \mathrm{X}_{\mathrm{prss}}+0.477 \mathrm{X}_{\mathrm{mm}}$ & Eq.5- CB7 & 54 & 1 & $\mathbf{0}$ \\
\hline 8 & $\begin{array}{l}\text { Strong Political Opposition / } \\
\text { Hostility }\end{array}$ & 0.000 & 0.914 & 1.961 & 0.000 & $\mathrm{Y}_{\mathrm{CB8} . \mathrm{I}}=-25.278+0.589 \mathrm{X}_{\mathrm{pmb}}+0.468 \mathrm{X}_{\mathrm{mmg}}$ & Eq.5-CB8 & 54 & 1 & 0 \\
\hline
\end{tabular}


Journal of Entrepreneurship and Project Management

ISSN 2520-9116 (Online)

\begin{tabular}{|c|c|c|c|c|c|c|c|c|c|c|}
\hline \multirow{2}{*}{ SN } & \multirow{2}{*}{ Cost Risk Description } & \multicolumn{6}{|c|}{ Regression Analysis } & \multirow{2}{*}{$\begin{array}{c}\text { Valid } \\
\text { Sample } \\
\text { Size }\end{array}$} & \multirow{2}{*}{$\begin{array}{l}\text { Number of } \\
\text { Iterations }\end{array}$} & \multirow{2}{*}{$\begin{array}{l}\text { Number } \\
\text { of Outlier }\end{array}$} \\
\hline & & Sig. & $\begin{array}{l}\text { R- } \\
\text { Square }\end{array}$ & $\begin{array}{l}\text { Durbin- } \\
\text { Watson }\end{array}$ & $\begin{array}{c}\text { Std. } \\
\text { Residual }\end{array}$ & Equation & $\begin{array}{l}\text { Equation } \\
\text { Reference }\end{array}$ & & & \\
\hline 9 & $\begin{array}{l}\text { Expropriation/Nationalization of } \\
\text { Assets }\end{array}$ & 0.000 & 0.893 & 1.563 & 0.000 & $\mathrm{Y}_{\mathrm{CBD} .1}=-25.173+0.577 \mathrm{X}_{\mathrm{prab}}+0.449 \mathrm{X}_{\mathrm{mpp}}$ & Eq.5- CB9 & 54 & 1 & $\mathbf{0}$ \\
\hline 10 & Inability of Concessionaire & 0.000 & 0.632 & 2.079 & 0.000 & $Y_{\text {CB10.1 }}=-6.461+0.106 X_{p m b}+0.520 X_{i m}$ & Eq.5-CB10 & 54 & 1 & $\mathbf{0}$ \\
\hline c & \multicolumn{10}{|l|}{ Legal Risks } \\
\hline 1 & Change in Tax Regulation & 0.000 & 0.978 & 1.513 & 0.000 & $\mathrm{Y}_{\mathrm{CCL} . \mathrm{le}}=-26.870+0.598 \mathrm{X}_{\mathrm{prab}}+0.506 \mathrm{X}_{\mathrm{ims}}$ & Eq.5- CC1 & 49 & 3 & 6 \\
\hline 2 & $\begin{array}{l}\text { Corruption and Lack of Respect for } \\
\text { Law }\end{array}$ & 0.000 & 0.918 & 1.925 & 0.000 & $Y_{\mathrm{cc}_{21}}=-25.470+0.609 \mathrm{X}_{\mathrm{prob}}+0.445 \mathrm{X}_{\mathrm{ims}}$ & Eq.5- CC2 & 54 & 1 & 0 \\
\hline 3 & Legislation Change & 0.000 & 0.938 & 1.888 & 0.000 & $\mathrm{Y}_{\mathrm{cc} 21}=-23.051+0.481 \mathrm{X}_{\mathrm{prob}}+0.522 \mathrm{X}_{\mathrm{im}}$ & Eq.5- CC3 & 54 & 1 & $\mathbf{0}$ \\
\hline 4 & Import / Export Restrictions & 0.000 & 0.942 & 1.927 & 0.000 & $\mathrm{Y}_{\mathrm{ccct.}}=-23.137+0.511 \mathrm{X}_{\mathrm{prob}}+0.493 \mathrm{X}_{\mathrm{img}}$ & Eq.5- $\mathrm{CC} 4$ & 54 & 1 & $\mathbf{0}$ \\
\hline 5 & Rate of Retum Restrictions & 0.000 & 0.925 & 1.937 & 0.000 & $\mathrm{Y}_{\text {CCS.1 }}=-15.100+0.424 \mathrm{X}_{\mathrm{prob}}+0.440 \mathrm{X}_{\mathrm{img}}$ & Eq.5- CC5 & 54 & 1 & $\mathbf{0}$ \\
\hline 6 & Industrial Regulatory Change & 0.000 & 0.936 & 1.592 & 0.000 & $\mathrm{Y}_{\mathrm{ccc6}, 1}=-21.128+0.524 \mathrm{X}_{\mathrm{prob}}+0.455 \mathrm{X}_{\mathrm{img}}$ & Eq.5- CC6 & 54 & 1 & $\mathbf{0}$ \\
\hline $\mathbf{D}$ & \multicolumn{10}{|l|}{ Economic Change Risks } \\
\hline 1 & Interest Rate Volatility & 0.000 & 0.961 & 2.098 & 0.000 & $Y_{C D L .1}=-16.208+0.330 X_{p r o b}+0.571 X_{i m p}$ & Eq.5-CD1 & 54 & 1 & $\mathbf{0}$ \\
\hline 2 & Inflation Rate Volatility & 0.000 & 0.968 & 1.979 & 0.000 & $Y_{C D 21}=-19.016+0.311 X_{p_{\mathrm{rob}}}+0.643 \mathrm{X}_{\mathrm{img}}$ & Eq.5- CD2 & 54 & 1 & $\mathbf{0}$ \\
\hline 3 & Foreign Exchange and Convert & 0.000 & 0.916 & 2.034 & 0.000 & $Y_{C D D .1}=-20.731+0.503 X_{\text {prob }}+0.439 X_{\text {imp }}$ & Eq.5-CD3 & 54 & 1 & $\mathbf{0}$ \\
\hline 4 & Poor Financial Market & 0.000 & 0.936 & 1.543 & 0.000 & $Y_{\text {CDA.1e }}=-27.743+0.545 X_{\text {prob }}+0.536 X_{\text {ing }}$ & Eq.5-CD4 & 51 & 3 & 3 \\
\hline $\mathbf{E}$ & \multicolumn{10}{|l|}{ Natural Risks } \\
\hline 1 & Force Majeure & 0.000 & 0.845 & 2.121 & 0.000 & $\mathrm{Y}_{\mathrm{CEE} .1}=-20.450+0.487 \mathrm{X}_{\mathrm{prob}}+0.425 \mathrm{X}_{\mathrm{imp}}$ & Eq.5-CE1 & 54 & 1 & $\mathbf{0}$ \\
\hline 2 & Environment & 0.000 & 0.921 & 1.754 & 0.000 & $\mathrm{Y}_{\mathrm{CE} 2.1}=-17.785+0.366 \mathrm{X}_{\mathrm{prat}}+0.513 \mathrm{X}_{\text {imp }}$ & Eq.5- CE2 & 54 & 1 & 0 \\
\hline 3 & Weather & 0.000 & 0.959 & 2.286 & 0.000 & $Y_{\text {CEB.1 }}=-15.315+0.245 X_{\text {prob }}+0.649 X_{\text {bmp }}$ & Eq.5. CE3 & 54 & 1 & $\mathbf{0}$ \\
\hline 4 & Geotechnical Condition & 0.000 & 0.929 & 1.633 & 0.000 & $Y_{\text {CEA.1 }}=-17.785+0.254 X_{\text {prob }}+0.628 X_{\text {bmp }}$ & Eq.5. CE4 & 54 & 1 & 0 \\
\hline
\end{tabular}

\begin{tabular}{|c|c|c|c|c|c|c|c|c|c|c|}
\hline \multirow{2}{*}{ SN } & \multirow{2}{*}{ Cost Risk Description } & \multicolumn{6}{|c|}{ Regression Analysis } & \multirow{2}{*}{$\begin{array}{c}\text { Valid } \\
\text { Sample } \\
\text { Size }\end{array}$} & \multirow{2}{*}{$\begin{array}{l}\text { Number of } \\
\text { Iterations }\end{array}$} & \multirow{2}{*}{$\begin{array}{l}\text { Number } \\
\text { of Outlier }\end{array}$} \\
\hline & & Sig. & \begin{tabular}{|l|} 
R- \\
Square \\
\end{tabular} & $\begin{array}{l}\text { Durbin- } \\
\text { Watson }\end{array}$ & $\begin{array}{l}\text { Std. } \\
\text { Residual } \\
\end{array}$ & Equation & \begin{tabular}{|l|} 
Equation \\
Reference
\end{tabular} & & & \\
\hline $\mathbf{F}$ & \multicolumn{10}{|l|}{ Market Risks } \\
\hline 1 & Market Supply & 0.000 & 0.917 & 1.704 & 0.000 & $Y_{C F 1.1}=-18.239+0.446 \mathrm{X}_{\mathrm{prbs}}+0.473 \mathrm{X}_{\mathrm{im}}$ & Eq.5-CF1 & 54 & 1 & 0 \\
\hline 2 & Market Demand & 0.000 & 0.966 & 1.772 & 0.000 & $Y_{C F 21}=-21.383+0.379 X_{p r b s}+0.654 X_{\text {ima }}$ & Eq.5-CF2 & 54 & 1 & 0 \\
\hline 3 & $\begin{array}{l}\text { Fluctuation of Material Cost by } \\
\text { Public/Private }\end{array}$ & 0.000 & 0.951 & 1.726 & 0.000 & $Y_{C F 3.1}=-26.299+0.523 X_{p r b s}+0.541 X_{i m p}$ & Eq.5- CF3 & 54 & 1 & 0 \\
\hline 4 & Value of Production Effort & 0.000 & 0.916 & 2.236 & 0.000 & $Y_{\text {CF4. }}=-20.887+0.429 X_{\text {prob }}+0.529 X_{i m}$ & Eq.5-CF4 & 54 & 1 & 0 \\
\hline G & \multicolumn{10}{|l|}{ Project Selection Risks } \\
\hline 1 & Public Opposition to Projects & 0.000 & 0.867 & 2.200 & 0.000 & $\mathrm{Y}_{\mathrm{CGL}, 1}=-13.799+0.432 \mathrm{X}_{\mathrm{prob}}+0.401 \mathrm{X}_{\mathrm{imp}}$ & Eq.5- CG1 & 54 & 1 & 0 \\
\hline 2 & Uncompetitive Tender & 0.000 & 0.985 & 1.604 & 0.000 & $Y_{c G 2.1 \mathrm{f}}=-30.589+0.446 \mathrm{X}_{\mathrm{pmb}}+0.738 \mathrm{X}_{\text {imp }}$ & Eq.5- CG2 & 44 & 6 & 10 \\
\hline 3 & Level of Demand for the Project & 0.000 & 0.910 & 1.598 & 0.000 & $Y_{C G 3.1}=-23.854+0.532 X_{p r o b}+0.466 X_{\text {imp }}$ & Eq.5- CG3 & 54 & 1 & 0 \\
\hline 4 & Land Acquisition & 0.000 & 0.870 & 1.857 & 0.000 & $Y_{\text {CG } 4.1}=-17.187+0.377 X_{p r o b}+0.520 X_{i m p}$ & Eq.5- CG4 & 54 & 1 & 0 \\
\hline 5 & Competition Risk & 0.000 & 0.949 & 1.836 & 0.000 & $Y_{C G 5.1}=-17.931+0.334 X_{p r o b}+0.594 X_{i m p}$ & Eq.5- CG5 & 54 & 1 & 0 \\
\hline $\mathbf{H}$ & \multicolumn{10}{|l|}{ Project Finance Risks } \\
\hline 1 & Inaccurate Estimates & 0.000 & 0.954 & 2.089 & 0.000 & $\mathrm{Y}_{\mathrm{CH} L \mathrm{~L}}=-34.293+0.598 \mathrm{X}_{\mathrm{prab}}+0.603 \mathrm{X}_{\mathrm{imp}}$ & Eq.5- CH1 & 54 & 1 & 0 \\
\hline 2 & High Finance Cost & 0.000 & 0.927 & 2.149 & 0.000 & $\mathrm{Y}_{\mathrm{CH} 21}=-26.010+0.528 \mathrm{X}_{\mathrm{prab}}+0.521 \mathrm{X}_{\mathrm{imp}}$ & Eq.5- $\mathrm{CH} 2$ & 54 & 1 & 0 \\
\hline 3 & High Bidding Costs & 0.000 & 0.935 & 2.446 & 0.000 & $\mathrm{Y}_{\mathrm{CH} 3 \mathrm{~A}}=-26.230+0.518 \mathrm{X}_{\mathrm{prob}}+0.543 \mathrm{X}_{\mathrm{imp}}$ & Eq.5- CH3 & 54 & 1 & 0 \\
\hline 4 & Delay in Payment of Annuity & 0.000 & 0.901 & 1.982 & 0.000 & $\mathrm{Y}_{\mathrm{CH} 4 \mathrm{~A}}=-20.774+0.449 \mathrm{X}_{\mathrm{prob}}+0.521 \mathrm{X}_{\mathrm{imp}}$ & Eq.5- CH4 & 54 & 1 & 0 \\
\hline $\mathbf{5}$ & $\begin{array}{l}\text { Financial Attraction of Project to } \\
\text { Investors }\end{array}$ & 0.000 & 0.965 & 1.608 & 0.000 & $\mathrm{Y}_{\text {CH5 } 1}=-27.694+0.550 \mathrm{X}_{\mathrm{prob}}+0.525 \mathrm{X}_{\mathrm{imp}}$ & Eq.5- CH5 & 54 & 1 & 0 \\
\hline 6 & Lack of Creditworthiness & 0.000 & 0.880 & 2.289 & 0.000 & $\mathrm{Y}_{\mathrm{CH} .1}=-18.204+0.380 \mathrm{X}_{\mathrm{prob}}+0.532 \mathrm{X}_{\mathrm{mmp}}$ & Eq.5- CH6 & 54 & 1 & 0 \\
\hline 7 & Delay in Financial Closure & 0.000 & 0.925 & 2.150 & 0.000 & $\mathrm{Y}_{\mathrm{CH} / 1}=-30.516+0.567 \mathrm{X}_{\mathrm{prab}}+0.531 \mathrm{X}_{\mathrm{imp}}$ & Eq.5- $\mathrm{CH}_{7}$ & 54 & 1 & 0 \\
\hline
\end{tabular}




\begin{tabular}{|c|c|c|c|c|c|c|c|c|c|c|}
\hline \multirow{2}{*}{ SN } & \multirow{2}{*}{ Cost Risk Description } & \multicolumn{6}{|c|}{ Regression Analysis } & \multirow{2}{*}{$\begin{array}{c}\text { Valid } \\
\text { Sample } \\
\text { Size }\end{array}$} & \multirow{2}{*}{$\begin{array}{l}\text { Number of } \\
\text { Iterations }\end{array}$} & \multirow{2}{*}{$\begin{array}{l}\text { Number } \\
\text { of Outlie }\end{array}$} \\
\hline & & Sig. & $\begin{array}{l}\text { R- } \\
\text { Square }\end{array}$ & $\begin{array}{l}\text { Durbin- } \\
\text { Watson }\end{array}$ & $\begin{array}{l}\text { Std. } \\
\text { Residual }\end{array}$ & Equation & $\begin{array}{l}\text { Equation } \\
\text { Reference }\end{array}$ & & & \\
\hline 8 & Inability to Service Debt & 0.000 & 0.894 & 1.738 & 0.000 & $Y_{\text {CHB. }}=-28.090+0.536 X_{p m b}+0.504 X_{\text {imp }}$ & Eq.5-CH8 & 54 & 1 & $\mathbf{0}$ \\
\hline 9 & Lack of Govemment Guarantees & 0.000 & 0.947 & 1.822 & 0.000 & $Y_{\text {CH9.1s }}=-19.149+0.329 X_{\text {prob }}+0.635 X_{\text {imp }}$ & Eq.5-CH9 & 53 & 2 & 1 \\
\hline 10 & $\begin{array}{l}\text { Financer Unwilling to Take High } \\
\text { Risk }\end{array}$ & 0.000 & 0.922 & 2.350 & 0.000 & $\mathrm{Y}_{\mathrm{CH} 10.1}=-24.299+0.453 \mathrm{X}_{\mathrm{pmb}}+0.566 \mathrm{X}_{\mathrm{mp}}$ & Eq.5- CH10 & 54 & 1 & 0 \\
\hline $\mathbf{I}$ & \multicolumn{10}{|c|}{ Building Functionality and Serviceability Risks } \\
\hline 1 & Construction Time Delay & 0.000 & 0.964 & 2.047 & 0.000 & $\mathrm{Y}_{\mathrm{ClI} .1}=-31.763+0.483 \mathrm{X}_{\mathrm{pmb}}+0.685 \mathrm{X}_{\mathrm{bmp}}$ & Eq.5. C11 & 54 & 1 & 0 \\
\hline 2 & Material Availability & 0.000 & 0.966 & 1.868 & 0.000 & $\mathrm{Y}_{\mathrm{C12} 2 \mathrm{~b}}=-13.223+0.266 \mathrm{X}_{\mathrm{prob}}+0.561 \mathrm{X}_{\mathrm{bmp}}$ & Eq.5- CI2 & 50 & 2 & 4 \\
\hline 3 & Labor Availability & 0.000 & 0.959 & 1.729 & 0.000 & $\mathrm{Y}_{\mathrm{C} 12 \mathrm{1}}=-26.526+0.538 \mathrm{X}_{\mathrm{pmb}}+0.524 \mathrm{X}_{\mathrm{bmp}}$ & Eq.5- CI3 & 54 & 1 & 0 \\
\hline 4 & Poor Quality of Workmanship & 0.000 & 0.956 & 1.675 & 0.000 & $\mathrm{Y}_{\mathrm{C} u A .1}=-20.011+0.433 \mathrm{X}_{\mathrm{prob}}+0.542 \mathrm{X}_{\mathrm{img}}$ & Eq.5- CI4 & 54 & 1 & $\mathbf{0}$ \\
\hline 5 & $\begin{array}{l}\text { Default of Sub-Contractors or } \\
\text { Suppliers }\end{array}$ & 0.000 & 0.962 & 1.820 & 0.000 & $\mathrm{Y}_{\mathrm{CIS.}}=-27.842+0.493 \mathrm{X}_{\mathrm{pmb}}+0.605 \mathrm{X}_{\mathrm{bmp}}$ & Eq.5-CI5 & 54 & 1 & $\mathbf{0}$ \\
\hline 6 & Design \& Construction Complexity & 0.000 & 0.972 & 1.577 & 0.000 & $\mathrm{Y}_{\mathrm{C} 16 . \mathrm{le}}=-32.106+0.570 \mathrm{X}_{\mathrm{pmb}}+0.584 \mathrm{X}_{\mathrm{lm}}$ & Eq.5- CI6 & 54 & 1 & $\mathbf{0}$ \\
\hline 7 & Design Deficiency & 0.000 & 0.974 & 1.505 & 0.000 & $Y_{\mathrm{Cr} 7.1}=-36.247+0.674 \mathrm{X}_{\mathrm{pmb}}+0.556 \mathrm{X}_{\mathrm{imp}}$ & Eq.5- CI7 & 54 & 1 & $\mathbf{0}$ \\
\hline 8 & Late Design Change & 0.000 & 0.958 & 1.856 & 0.000 & $\mathrm{Y}_{\mathrm{c} 18.1}=-27.519+0.474 \mathrm{X}_{\mathrm{pmb}}+0.624 \mathrm{X}_{\mathrm{imp}}$ & Eq.5- CI8 & 54 & 1 & 0 \\
\hline 9 & $\begin{array}{l}\text { Construction Technology } \\
\text { Complexity }\end{array}$ & 0.000 & 0.945 & 2.061 & 0.000 & $\mathrm{Y}_{\mathrm{c} 19.1}=-23.389+0.408 \mathrm{X}_{\mathrm{pmb}}+0.573 \mathrm{X}_{\mathrm{imp}}$ & Eq.5- C19 & 54 & 1 & $\mathbf{0}$ \\
\hline 10 & Contractual Risk & 0.000 & 0.957 & 2.283 & 0.000 & $\mathrm{Y}_{\mathrm{cua.1}}=-21.148+0.410 \mathrm{X}_{\mathrm{prob}}+0.539 \mathrm{X}_{\mathrm{imp}}$ & Eq.5-CI10 & 54 & 1 & 0 \\
\hline 11 & Contractor Failure & 0.000 & 0.988 & 1.559 & 0.000 & $\mathrm{Y}_{\mathrm{CmId}}=-50.875+0.760 \mathrm{X}_{\mathrm{pmb}}+0.669 \mathrm{X}_{\mathrm{mmp}}$ & Eq.5-CI11 & 48 & 4 & 6 \\
\hline 12 & Quality and Reliability & 0.000 & 0.960 & 2.061 & 0.000 & $\mathrm{Y}_{\mathrm{Cl} 21}=-32.094+0.589 \mathrm{X}_{\mathrm{prob}}+0.553 \mathrm{X}_{\mathrm{imp}}$ & Eq.5- CI12 & 54 & 1 & $\mathbf{0}$ \\
\hline $\mathbf{J}$ & \multicolumn{10}{|l|}{ Stakeholders Relationship Risks } \\
\hline 1 & $\begin{array}{l}\text { Different Working Method Between } \\
\text { Partners }\end{array}$ & 0.000 & 0.943 & 1.969 & 0.000 & $\mathrm{Y}_{\mathrm{CNA}}=-15.742+0.319 \mathrm{X}_{\mathrm{pms}}+0.542 \mathrm{X}_{\mathrm{imp}}$ & Eq.5-CJ1 & 54 & 1 & $\mathbf{0}$ \\
\hline 2 & $\begin{array}{l}\text { Inadequate Experience in Residential } \\
\text { Projects }\end{array}$ & 0.000 & 0.894 & 1.694 & 0.000 & $\mathrm{Y}_{\mathrm{cs.1}}=-26.927+0.523 \mathrm{X}_{\mathrm{pmbs}}+0.517 \mathrm{X}_{\mathrm{imp}}$ & Eq.5-C.12 & 54 & 1 & $\mathbf{0}$ \\
\hline
\end{tabular}

\begin{tabular}{|c|c|c|c|c|c|c|c|c|c|c|}
\hline \multirow{2}{*}{ SN } & \multirow{2}{*}{ Cost Risk Description } & \multicolumn{6}{|c|}{ Regression Analysis } & \multirow{2}{*}{$\begin{array}{c}\text { Valid } \\
\text { Sample } \\
\text { Size }\end{array}$} & \multirow{2}{*}{$\begin{array}{l}\text { Number of } \\
\text { Iterations }\end{array}$} & \multirow{2}{*}{$\begin{array}{l}\text { Number } \\
\text { of Outlier }\end{array}$} \\
\hline & & Sig. & $\begin{array}{l}\mathrm{R}- \\
\text { Square }\end{array}$ & $\begin{array}{l}\text { Durbin- } \\
\text { Watson }\end{array}$ & $\begin{array}{c}\text { Std. } \\
\text { Residual }\end{array}$ & Equation & $\begin{array}{l}\text { Equation } \\
\text { Reference }\end{array}$ & & & \\
\hline 3 & $\begin{array}{l}\text { Lack of Commitment From } \\
\text { Public/Private Sector }\end{array}$ & 0.000 & 0.933 & 1.953 & 0.000 & $\mathrm{Y}_{\mathrm{CBA}}=-19.470+0.395 \mathrm{X}_{\mathrm{prat}}+0.508 \mathrm{X}_{\mathrm{imp}}$ & Eq.5- CJ3 & 54 & 1 & 0 \\
\hline 4 & Organization and Coordination Risk & 0.000 & 0.915 & 2.318 & 0.000 & $Y_{C M \mu}=-27.211+0.547 X_{p r b b}+0.490 X_{i m p}$ & Eq.5- CJ4 & 54 & 1 & 0 \\
\hline 5 & $\begin{array}{l}\text { Inadequate Distribution of } \\
\text { Responsibility \& Risk }\end{array}$ & 0.000 & 0.952 & 2.306 & 0.000 & $\mathrm{Y}_{\mathrm{C} \cdot \mathrm{B} . \mathrm{I}}=-21.988+0.371 \mathrm{X}_{\mathrm{prob}}+0.621 \mathrm{X}_{\mathrm{imp}}$ & Eq.5- CJ5 & 54 & 1 & $\mathbf{0}$ \\
\hline 6 & $\begin{array}{l}\text { Inadequate Negotiation Period Prior } \\
\text { to Initiation }\end{array}$ & 0.000 & 0.911 & 2.389 & 0.000 & $Y_{c .5 .1}=-20.968+0.457 X_{p r a b}+0.453 X_{i m p}$ & Eq.5- CJ6 & 54 & 1 & $\mathbf{0}$ \\
\hline 7 & $\begin{array}{l}\text { Conflict Between Project's } \\
\text { Participants }\end{array}$ & 0.000 & 0.944 & 2.241 & 0.000 & $\mathrm{Y}_{\mathrm{C} J 1}=-24.109+0.497 \mathrm{X}_{\mathrm{prab}}+0.512 \mathrm{X}_{\mathrm{imp}}$ & Eq.5- $\mathrm{CJ} 7$ & 54 & 1 & $\mathbf{0}$ \\
\hline 8 & Workers Strike & 0.000 & 0.913 & 2.016 & 0.000 & $Y_{\mathrm{CSB.1}}=-16.370+0.390 \mathrm{X}_{\mathrm{prab}}+0.484 \mathrm{X}_{\mathrm{imp}}$ & Eq.5- CJ8 & 54 & 1 & 0 \\
\hline 9 & $\begin{array}{l}\text { Cultural Differences Between Main } \\
\text { Stakeholders }\end{array}$ & 0.000 & 0.906 & 1.716 & 0.000 & $Y_{C B 1}=-14.387+0.373 X_{p r b s}+0.415 X_{i m p}$ & Eq.5- CJ9 & 54 & 1 & 0 \\
\hline $\mathbf{K}$ & \multicolumn{10}{|l|}{ Knowledge Risks } \\
\hline 1 & Expertise & 0.000 & 0.932 & 1.954 & 0.000 & $\mathrm{Y}_{\mathrm{CK} 1,1}=-28.386+0.475 \mathrm{X}_{\mathrm{prbb}}+0.604 \mathrm{X}_{\mathrm{imp}}$ & Eq.5-CK1 & 54 & 1 & 0 \\
\hline 2 & Familiarities & 0.000 & 0.947 & 1.989 & 0.000 & $Y_{\text {CK2.1 }}=-24.478+0.479 \mathrm{X}_{\mathrm{prob}}+0.524 \mathrm{X}_{\mathrm{imp}}$ & Eq.5- CK2 & 54 & 1 & $\mathbf{0}$ \\
\hline 3 & Number of Bidders & 0.000 & 0.974 & 1.582 & 0.000 & $Y_{\text {CK3.1 }}=-13.106+0.224 X_{\text {prob }}+0.598 X_{\text {imp }}$ & Eq.5- CK3 & 54 & 1 & $\mathbf{0}$ \\
\hline 4 & Market Conditions & 0.000 & 0.957 & 1.982 & 0.000 & $\mathrm{Y}_{\mathrm{CK} 4.1}=-20.929+0.386 \mathrm{X}_{\mathrm{prob}}+0.606 \mathrm{X}_{\mathrm{imp}}$ & Eq.5- CK4 & 54 & 1 & 0 \\
\hline 5 & Size of the Project & 0.000 & 0.920 & 1.806 & 0.000 & $Y_{\text {CK5.1 }}=-18.089+0.387 X_{\text {prob }}+0534 X_{\text {imp }}$ & Eq.5- CK5 & 54 & 1 & 0 \\
\hline 6 & Type of Building & 0.000 & 0.960 & 1.833 & 0.000 & $Y_{\mathrm{CK} 6.1}=-20.515+0.393 \mathrm{X}_{\mathrm{prob}}+0.566 \mathrm{X}_{\mathrm{imp}}$ & Eq.5- CK6 & 54 & 1 & 0 \\
\hline 7 & Extent of Database & 0.000 & 0.852 & 1.535 & 0.000 & $\mathrm{Y}_{\mathrm{CK} 7.1}=-13.046+0.333 \mathrm{X}_{\mathrm{prb}}+0.456 \mathrm{X}_{\mathrm{im}}$ & Eq.5- CK7 & 54 & 1 & 0 \\
\hline 8 & Homogeneity of Samples & 0.000 & 0.966 & 1.982 & 0.000 & $\mathrm{Y}_{\mathrm{CK} 8 \mathrm{~A}}=-9.893+0.212 \mathrm{X}_{\mathrm{prbs}}+0.534 \mathrm{X}_{\mathrm{img}}$ & Eq.5- CK8 & 54 & 1 & 0 \\
\hline 9 & Details of Information & 0.000 & 0.963 & 1.956 & 0.000 & $\mathrm{Y}_{\mathrm{CK} 9.1}=-20.361+0.374 \mathrm{X}_{\mathrm{prob}}+0.594 \mathrm{X}_{\mathrm{img}}$ & Eq.5- CK9 & 54 & 1 & 0 \\
\hline o & \multicolumn{10}{|l|}{ OPEX Activities' Risks } \\
\hline 1 & Energy Costs & 0.000 & 0.924 & 2.047 & 0.000 & $Y_{01.1}=-29.619+0.554 X_{p r o b}+0.554 X_{i m p}$ & Eq.5- 01 & 54 & 1 & 0 \\
\hline
\end{tabular}


Journal of Entrepreneurship and Project Management

ISSN 2520-9116 (Online)

Vol. 6, Issue No.1, pp 90 -114, 2021

www.carijournals.org

\begin{tabular}{|c|c|c|c|c|c|c|c|c|c|c|}
\hline \multirow{2}{*}{$\mathrm{SN}$} & \multirow{2}{*}{ Cost Risk Description } & \multicolumn{6}{|c|}{ Regression Analysis } & \multirow{2}{*}{$\begin{array}{c}\text { Valid } \\
\text { Sample } \\
\text { Size }\end{array}$} & \multirow{2}{*}{$\begin{array}{l}\text { Number of } \\
\text { Iterations }\end{array}$} & \multirow{2}{*}{$\begin{array}{c}\text { Number } \\
\text { of Outlier }\end{array}$} \\
\hline & & Sig. & $\begin{array}{l}\mathrm{R}- \\
\text { Square }\end{array}$ & $\begin{array}{l}\text { Durbin- } \\
\text { Watson }\end{array}$ & $\begin{array}{c}\text { Std. } \\
\text { Residual }\end{array}$ & Equation & $\begin{array}{l}\text { Equation } \\
\text { Reference }\end{array}$ & & & \\
\hline 2 & $\begin{array}{l}\text { Service Life of Building } \\
\text { Components }\end{array}$ & 0.000 & 0.961 & 1.663 & 0.000 & $Y_{02.1}=-19.639+0.355 X_{p ~ r o b}+0.593 X_{\text {inp }}$ & Eq.5- $\mathrm{O} 2$ & 54 & 1 & 0 \\
\hline 3 & Building Components' Eco-Costs & 0.000 & 0.885 & 1.858 & 0.000 & $Y_{03.1}=-14.620+0.312 X_{p r o b}+0.499 X_{\text {inp }}$ & Eq.5- O3 & 54 & 1 & 0 \\
\hline 4 & Asset Operation Eco-Costs & 0.000 & 0.939 & 1.975 & 0.000 & $Y_{04.1}=-13.456+0.272 X_{p r o b}+0.544 X_{\text {inp }}$ & Eq.5- 04 & 54 & 1 & 0 \\
\hline 5 & Disposal Eco-Costs & 0.000 & 0.958 & 1.768 & 0.000 & $Y_{05.1}=-11.825+0.247 X_{p r o b}+0.549 X_{\text {imp }}$ & Eq.5- O5 & 54 & 1 & 0 \\
\hline 6 & Components' Deterioration Rate & 0.000 & 0.940 & 2.305 & 0.000 & $Y_{06.1}=-15.652+0.329 X_{p r o b}+0.553 X_{\text {inp }}$ & Eq.5- O6 & 54 & 1 & 0 \\
\hline 7 & Fabric Maintenance & 0.000 & 0.922 & 2.388 & 0.000 & $Y_{07.1}=-14.582+0.277 X_{p \text { rob }}+0.535 X_{\text {imp }}$ & Eq.5- 07 & 54 & 1 & 0 \\
\hline 8 & Services & 0.000 & 0.934 & 1.639 & 0.000 & $Y_{08.1}=-14.609+0.252 X_{p r o b}+0.596 X_{\text {inp }}$ & Eq.5- 08 & 54 & 1 & 0 \\
\hline 9 & Equipment's Maintenance & 0.000 & 0.977 & 1.914 & 0.000 & $Y_{09.1 \mathrm{~b}}=-16.289+0.305 \mathrm{X}_{\mathrm{prob}}+0.558 \mathrm{X}_{\mathrm{imp}}$ & Eq.5- 09 & 51 & 2 & 3 \\
\hline 10 & Overheads & 0.000 & 0.954 & 1.778 & 0.000 & $Y_{O 10.1}=-21.626+0.349 X_{p r o b}+0.615 X_{\text {imp }}$ & Eq.5- 010 & 54 & 1 & 0 \\
\hline 11 & Utilities & 0.000 & 0.962 & 2.303 & 0.000 & $Y_{011.1}=-16.552+0.294 X_{p r o b}+0.554 X_{\text {imp }}$ & Eq.5- 011 & 54 & 1 & 0 \\
\hline 12 & Cleaning & 0.000 & 0.836 & 1.901 & 0.000 & $Y_{012.1}=-14.313+0.285 X_{\text {prob }}+0.480 X_{\text {inp }}$ & Eq.5- 012 & 54 & 1 & 0 \\
\hline 13 & $\begin{array}{l}\text { Percentage of Current Replacement } \\
\text { Value }\end{array}$ & 0.000 & 0.934 & 2.041 & 0.000 & $Y_{\text {o13.1 }}=-15.053+0.287 X_{p r o b}+0.539 X_{\text {imp }}$ & Eq.5- O13 & 54 & 1 & 0 \\
\hline 14 & Ratio of Maintenance to Capital Cost & 0.000 & 0.942 & 2.123 & 0.000 & $Y_{014.1}=-14.588+0.291 X_{p r o b}+0.538 X_{\text {imp }}$ & Eq.5- 014 & 54 & 1 & 0 \\
\hline 15 & Ratio of Operation to Capital Cost & 0.000 & 0.949 & 2.124 & 0.000 & $Y_{015.1}=-17.726+0.363 X_{p r o b}+0.525 X_{\text {inp }}$ & Eq.5- 015 & 54 & 1 & 0 \\
\hline
\end{tabular}

